\title{
Article \\ Soybean Nutrition in a Novel Single-Nutrient Source Hydroponic Solution
}

\author{
David L. Cole ${ }^{1}$, Savannah J. Kobza ${ }^{2}$, Savannah R. Fahning ${ }^{2}$, Samuel H. Stapley ${ }^{2}$, Dicken K. A. Bonsrah ${ }^{2}$, \\ Rachel L. Buck ${ }^{2}$ and Bryan G. Hopkins ${ }^{2, *(D)}$ \\ 1 Chemical and Biological Engineering Department, University of Wisconsin-Madison, Madison, \\ WI 53706, USA; dlcole3@wisc.edu \\ 2 Plant and Wildlife Sciences Department, Brigham Young University, Provo, UT 84602, USA; \\ savannahkobza24@gmail.com (S.J.K.); savfahning@gmail.com (S.R.F.); samuel.h.stapley@gmail.com (S.H.S.); \\ dickenbonsrah@gmail.com (D.K.A.B.); rachelbuck@byu.edu (R.L.B.) \\ * Correspondence: Hopkins@byu.edu
}

\section{check for}

updates

Citation: Cole, D.L.; Kobza, S.J.; Fahning, S.R.; Stapley, S.H.; Bonsrah, D.K.A.; Buck, R.L.; Hopkins, B.G. Soybean Nutrition in a Novel Single-Nutrient Source Hydroponic Solution. Agronomy 2021, 11, 523. https://doi.org/10.3390/agronomy 11030523

Academic Editors: Alessandro Miceli, Gian Attilio Sacchi and Fabio Francesco Nocito

Received: 30 December 2020

Accepted: 5 March 2021

Published: 11 March 2021

Publisher's Note: MDPI stays neutral with regard to jurisdictional claims in published maps and institutional affiliations.

Copyright: (c) 2021 by the authors. Licensee MDPI, Basel, Switzerland. This article is an open access article distributed under the terms and conditions of the Creative Commons Attribution (CC BY) license (https:// creativecommons.org/licenses/by/ $4.0 /)$.
Abstract: Hydroponic systems are efficient for studying plant nutrition. It is often desirable to adjust individual nutrients for unique species' needs and/or to create multiple nutrient deficiencies within the same study. However, this is challenging to do with traditional solutions as nutrients are generally added as dual nutrient salts, such as when varying phosphorus $(\mathrm{P})$ concentration also affects nitrogen concentration; potentially, the chemical form of the nutrient taken up when ammonium phosphate is the source for $\mathrm{P}$. This can create unintended consequences with nutrients other than those intended for adjustment. A new hydroponic system has been created to allow for nutrient deficiencies using single-nutrient sources, including ammonium nitrate; phosphoric, sulfuric, hydrochloric, and boric acids; potassium, calcium, magnesium, zinc, and copper carbonates; manganese acetate; sodium molybdate; iron EDDHA; with HEDTA as an additional chelate. This nutrient solution was compared to a traditional "Hoagland" hydroponic solution to grow soybean (Glycine max (L.) Merr). Additional treatments included alteration of $\mathrm{pH}$ in the new solution as well as evaluating varying levels of calcium, magnesium, and manganese. This new solution proved effective, as soybean was grown to maturity and performed as well as the traditional Hoagland solution. Adjusting $\mathrm{pH}$ downward with hydrochloric acid resulted in healthy plants, but solution $\mathrm{pH}$ was not adequately buffered. Adjusting $\mathrm{pH}$ with acetic acid resulted in toxicity. Further work is required to provide better $\mathrm{pH}$ buffering and approximately align tissue nutrient concentrations with field-grown soybean.

Keywords: Glycine max; soybean; nutrient uptake; hydroponic; calcium; magnesium; manganese; nitrogen; phosphorus; potassium; micronutrients; nutrient deficiency

\section{Introduction}

Understanding nutrient deficiency symptoms and plant tissue critical levels aids in achieving proper nutrient management in crops. Knowledge of these characteristics is increasingly important as a vital aspect of providing the food, fuel, and fiber needed for Earth's ever-growing population. The goal of such efforts is to achieve maximum economic yield while conserving natural resources and minimizing nutrient pollution.

Hydroponic and related systems are the simplest and most rapid methods of providing information for plant nutrition [1-6]. Soil-based studies are vital for applying crop research intended to guide field-crop management, but hydroponic studies can be used for basic or foundational science studies as well as to understand applications for commercial hydroponic growth systems. Although there are differences in growing plants in hydroponics vs. soil, there are also ample similarities and correlations. For example, Summerhays et al. $[7,8]$ found similar results between plants grown in soil and those grown hydroponically. Furthermore, it is generally not possible to create most or all of the mineral nutrient deficiencies in comparative trials in soil because it typically contains a bank of nutrient 
reserves [9]. It is especially difficult to create multiple micronutrient and/or secondary macronutrient deficiencies in some soils. In contrast, hydroponic systems potentially enable the induction of every mineral nutrient deficiency in a comparative study in a controlled environment, enabling the efficient study of basic plant nutrition studies [1,4,5].

Many hydroponic solutions are available, such as Hoagland and Arnon [10] and Steinberg [11]. In many cases, the original published solutions have been modified to study chemistry impacts such as $\mathrm{pH}$ [12], and various hydroponic solutions have been used to create individual nutrient deficiencies, such as nitrogen $(\mathrm{N})[13,14]$, phosphorus (P) [8,15-20], potassium (K) [21], sulfur (S) [22], calcium (Ca) [23,24], magnesium (Mg) [25], iron (Fe) [21,26-29], zinc (Zn) [15,17-19,30], manganese (Mn) [16,18,31], copper $(\mathrm{Cu})[32]$, boron (B) [33], molybdenum (Mo) [11], chloride (Cl) [34], and nickel (Ni) [35].

Interactions of some of these and other minerals have also been evaluated, such as $P$ and $\mathrm{Zn}[15,17,19], \mathrm{P}$ and $\mathrm{Mn}$ [16], P, Zn, and Mn [18], and cadmium (Cd) with $\mathrm{Zn}, \mathrm{Cu}, \mathrm{Mn}$, and Fe [36].

Unfortunately, unintended interacting factors can result when attempting to study nutrients or to create deficiencies where the accompanying ion (usually ammonium, calcium, chloride, nitrate, and/or sulfate) of the desired nutrient is simultaneously impacted as the concentration of the desired nutrient is varied. This often occurs because the traditional hydroponic solutions are made with many dual nutrient compounds, where the compounds are cationic and anionic nutrient salts. For example, if magnesium sulfate is the Mg source, lowering the $\mathrm{Mg}$ concentration simultaneously lowers the $\mathrm{S}$ concentration [1].

To help reduce interacting factors, a new hydroponic solution that will allow individual nutrient concentrations to be altered without influencing other nutrients is needed. Such a solution would provide easier development of optimal, custom recipes for individual species/varieties and/or enable nutrient deficiencies for research purposes. Such a solution was developed in the Hopkins Biophysical Chemistry Research Group at Brigham Young University. Preliminary studies showed this solution to be effective for growing plants and creating $\mathrm{N}$ deficiencies in quinoa (Chenopodium quinoa Willd.; [1]) and soybean (Glycine max (L.) Merr; [37]). However, these initial findings have no comparison to contemporary nutrient solutions that have been shown to grow plants effectively. The objective of this study is to evaluate soybean to compare this new solution to the traditional "Hoagland" solution [10] and to determine the feasibility of adjusting $\mathrm{pH}$ in this new solution with acetic $\left(\mathrm{C}_{2} \mathrm{H}_{4} \mathrm{O}_{2}\right)$ or hydrochloric $(\mathrm{HCl})$ acid. Additionally, $\mathrm{Ca}, \mathrm{Mg}$, and $\mathrm{Mn}$ concentrations were varied in this new solution to explore more optimal concentrations for these nutrients as a result of initial findings [1]. Soybean was selected due to its global importance [38] as well as the availability of significant field [9,39-43] and hydroponic data $[20,27-29]$ for comparison.

\section{Materials and Methods}

\subsection{Growing Environment}

Soybean was grown in an environmentally controlled growth chamber from August to September 2019 at Brigham Young University in Provo, UT, USA, at $1400 \mathrm{~m}$ elevation (40.245-111.650). Lighting was supplied by a combination of metal halide and highpressure Na lamps, with 1800 and $1000 \mu \mathrm{mol}$ (photons) $\mathrm{m}^{-2} \cdot \mathrm{s}^{-1}$ of photosynthetically active radiation (AccuPAR LP-80, Meter Group, Inc. (formerly Decagon Devices, Inc.), Pullman, WA, USA) at a distance of 30 and $110 \mathrm{~cm}$, respectively, from the light source. Plants were grown in a $16 / 8 \mathrm{~h}$ light/dark photoperiod. Temperatures were $21 \pm 1{ }^{\circ} \mathrm{C}$ for the dark photoperiod, $23 \pm 1{ }^{\circ} \mathrm{C}$ during the first $4 \mathrm{~h}$, and $29 \pm 1^{\circ} \mathrm{C}$ for the remainder of the light photoperiod.

Each experimental unit consisted of soybean grown in a 14-L plastic container $(29 \mathrm{~cm}$ inside diameter, $27 \mathrm{~cm}$ height) filled with a hydroponic solution. The containers were placed into opaque wooden boxes and covered with opaque plastic lids $1 \mathrm{~cm}$ thick. Each lid had eight $(5.0 \mathrm{~cm}$ diameter) holes for plants that were completely covered by fittings and a smaller diameter access hole in the center that was completely covered with opaque plastic 
to exclude light from the roots and nutrient solution. The fittings for holding plants $(4.8 \mathrm{~cm}$ inside diameter, $2.3 \mathrm{~cm}$ height above the plastic lid, $1.8 \mathrm{~cm}$ threaded side that extended below the lid) were secured to the underside of the lid with threaded rings. Two layers of white nylon matte mesh $(2 \times 4 \mathrm{~mm})$ netting material were stretched tightly and placed over the threaded side of the fitting and secured in place with the threaded ring. Gravel $(2.0-4.8 \mathrm{~mm})$ was rinsed with deionized water and placed on the taut netting inside the fittings to a depth of $3.0 \mathrm{~cm}$. The system in this study was identical, with the exception of oxygen tube placement, to that shown in photographs by Cole et al. [1].

Three to five soybean ("NK S46-A1") seeds, obtained from Syngenta (Basel, Switzerland), were germinated in each fitting by placing them on gravel $\sim 1.5 \mathrm{~cm}$ below the top of the fitting and covering with $\sim \mathrm{cm}$ of gravel. The seeds were watered daily from the top of the fitting using deionized water until their roots were of sufficient length to reach the nutrient solution.

Oxygen was supplied to the solution through PVC tubing passed through a small hole in the side of the boxes into the nutrient solution. Cylindrical bubbler air stones $(12 \mathrm{~mm}$ diameter with $25 \mathrm{~mm}$ length), commonly used in aquariums, were attached to the end of the tubing to diffuse the size of air bubbles. These stones were evaluated by soaking in deionized water, which was analyzed and found to have no nutrient contamination other than negligible amounts of $\mathrm{S}, \mathrm{Ca}$, and $\mathrm{B}$. The airflow rate was high enough to have visible effervescence but low enough to avoid bubbling the solution out of the container.

\subsection{Treatment and Block Design}

Seven treatments (Table 1) were established just prior to planting in a randomized complete block design (RCBD) with three replicated blocks. After $27 \mathrm{~d}$, it appeared that there was a growth difference based on where plants were located within the growth chamber. The three blocks were adjusted to account for this variability, and treatments were randomized within these new block locations.

Table 1. Treatments for a soybean hydroponic nutrition study. The acids for $\mathrm{pH}$ adjustment were at 1.1 and $1.8 \mathrm{M}$ for hydrochloric $(\mathrm{HCl})$ and acetic (AA) acids, respectively. When noted, the $\mathrm{Mn}$ increase was $25 \%$, Ca decreased $21 \%$, and $\mathrm{Mg}$ decreased $73 \%$ compared to the standard Hopkins $(\mathrm{H})$ or single-nutrient source (SNS) solution (see Table 2 for concentrations for base Hopkins SNS and Hoagland solutions).

\begin{tabular}{cccc}
\hline $\begin{array}{c}\text { Treatment } \\
\text { Number }\end{array}$ & Treatment ID & Nutrient Solution & $\begin{array}{c}\mathbf{p H} \\
\text { Adjustment }\end{array}$ \\
\hline 1 & ctrl & Hoagland & None \\
2 & $\mathrm{H}$ & Hopkins SNS & None \\
3 & $\mathrm{H}-\mathrm{HCl}$ & Hopkins SNS & $\mathrm{HCl}$ \\
4 & $\mathrm{H}-\mathrm{AA}$ & Hopkins SNS & acetic acid \\
5 & $\mathrm{H}-\mathrm{Ca} / \mathrm{Mg}$ & Hopkins SNS with Ca/Mg decrease & acetic acid \\
6 & $\mathrm{H}-\mathrm{Ca} / \mathrm{Mg}+\mathrm{Mn}$ & Hopkins SNS with Mn increase and & acetic acid \\
7 & $\mathrm{H}-\mathrm{Ca}\left(\mathrm{C}_{2} \mathrm{H}_{3} \mathrm{O}_{2}\right)_{2}$ & Hopkins SNS with Ca from Ca acetate & acetic acid \\
\hline
\end{tabular}


Table 2. Hydroponic nutrient concentrations $(\mu \mathrm{M})$ for the Hoagland solution [10] and Hopkins' single nutrient source (SNS) solution.

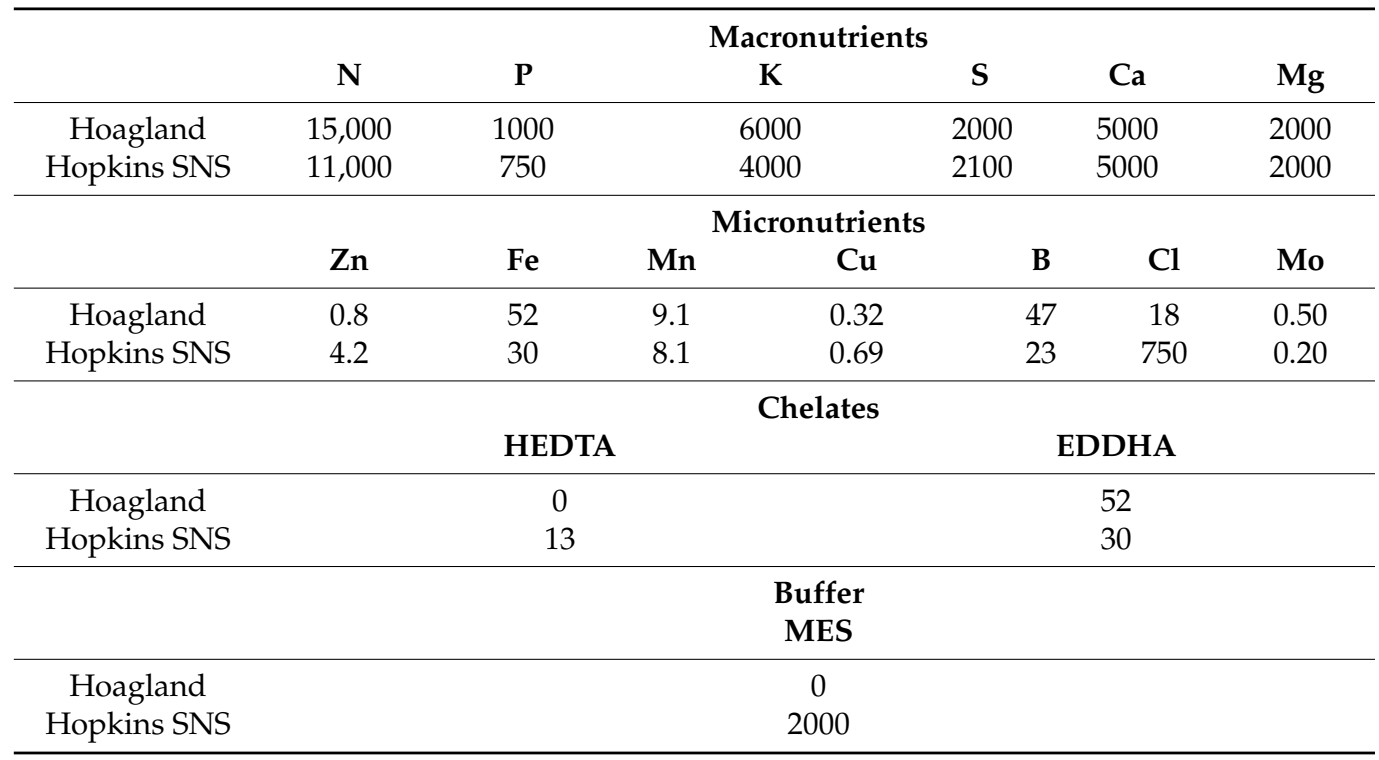

Treatment 1 was a positive control using a traditional hydroponic solution [10], referred to hereafter as the "Hoagland" solution (Table 2). Treatment 2 was a solution developed by the Hopkins Biophysical Chemistry Research Group at Brigham Young University (Table 2), similar to the solution from a quinoa study [1]. This solution contained what was estimated to be optimal concentrations of all nutrients based initially on Barben et al. [15-18] and Nichols et al. [19], with modifications based on preliminary observational studies conducted by Hopkins (data not shown) and the findings of Cole et al. [1]. Treatments 3 and 4 were identical to Treatment 2 but with $\mathrm{pH}$ adjustment of $\mathrm{HCl}$ or acetic acid, respectively. Treatment 5 was similar to Treatment 4 but had $21 \%$ less Ca and $73 \%$ less $\mathrm{Mg}$ in the nutrient solution. Likewise, Treatment 6 was identical to Treatment 5 but had $25 \%$ more $\mathrm{Mn}$ in the nutrient solution. Treatments 5 and 6 were included because preliminary data were based on lower $\mathrm{Ca}$ and $\mathrm{Mg}$ levels and higher Mn levels, with Treatment 6 most closely matching the solution used by Cole et al. [1]. Treatment 7 had identical concentrations to Treatment 2, but its Ca source was from calcium acetate $\left(\mathrm{Ca}\left(\mathrm{C}_{2} \mathrm{H}_{3} \mathrm{O}_{2}\right)_{2}\right)$ rather than calcium carbonate $\left(\mathrm{CaCO}_{3}\right)$.

Treatment 7 was discontinued at $20 \mathrm{~d}$ because shoot and root growth were extremely stunted, and the nutrient solution for all replicates had an extremely pungent odor and microbial growth. It is noteworthy that the $\mathrm{pH}$ proved to be very difficult to adjust for this treatment. Thus, this treatment showed early on that it was not suitable for hydroponics, and it was abandoned with no further evaluation.

The concentrations in Table 2 for the Hoagland "ctrl" nutrient solution were derived from the following (note that most of these are dual nutrient sources):

- $\quad$ potassium $\left(\mathrm{KNO}_{3}\right)$ and calcium $\left[\mathrm{Ca}\left(\mathrm{NO}_{3}\right)_{2} \cdot 4 \mathrm{H}_{2} \mathrm{O}\right]$ nitrates;

- monopotassium phosphate $\left(\mathrm{KH}_{2} \mathrm{PO}_{4}\right)$;

- magnesium $\left(\mathrm{MgSO}_{4} \cdot 7 \mathrm{H}_{2} \mathrm{O}\right)$, zinc $\left(\mathrm{ZnSO}_{4} \cdot 7 \mathrm{H}_{2} \mathrm{O}\right)$, and copper $\left(\mathrm{CuSO}_{4} \cdot 5 \mathrm{H}_{2} \mathrm{O}\right)$ sulfates;

- manganese chloride $\left(\mathrm{MnCl}_{2} \cdot 5 \mathrm{H}_{2} \mathrm{O}\right)$;

- $\quad$ boric acid $\left(\mathrm{H}_{3} \mathrm{BO}_{3}\right)$;

- $\quad$ sodium molybdate $\left(\mathrm{Na}_{2} \mathrm{MoO}_{4} \cdot 2 \mathrm{H}_{2} \mathrm{O}\right)$;

- $\quad$ iron $6 \%$ ethylenediamine- $N, N^{\prime}$-bis(2-hydroxyphenylacetic) acid (EDDHA) chelate.

The concentrations in Table 2 for the Hopkins single-nutrient source (SNS) solution or " $\mathrm{H}$ " nutrient solution were derived from the following (note that, in contrast to the control, all are single essential mineral nutrient sources):

- $\quad$ ammonium nitrate $\left(\mathrm{NH}_{4} \mathrm{NO}_{3}\right)$; 
- $\quad$ acids: $\mathrm{HCl}$, phosphoric $\left(\mathrm{H}_{3} \mathrm{PO}_{4}\right), \mathrm{H}_{3} \mathrm{BO}_{3}$, and sulfuric $\left(\mathrm{H}_{2} \mathrm{SO}_{4}\right)$;

- carbonates: potassium carbonate $\left(\mathrm{K}_{2} \mathrm{CO}_{3}\right)$, calcium carbonate $\left(\mathrm{CaCO}_{3}\right)$, zinc carbonate $\left(\mathrm{ZnCO}_{3}\right)$, dicopper carbonate dihydroxide $\left(\mathrm{CuCO}_{3} \cdot \mathrm{Cu}(\mathrm{OH})_{2}\right)$, magnesium carbonate hydroxide pentahydrate $\left(4 \mathrm{MgCO}_{3} \cdot \mathrm{Mg}(\mathrm{OH})_{2} \cdot 5 \mathrm{H}_{2} \mathrm{O}\right)$;

- manganese acetate $\left(\mathrm{Mn}\left(\mathrm{C}_{2} \mathrm{H}_{3} \mathrm{O}_{2}\right)_{2} \cdot 4 \mathrm{H}_{2} \mathrm{O}\right)$;

- $\mathrm{Na}_{2} \mathrm{MoO}_{4} \cdot 2 \mathrm{H}_{2} \mathrm{O}$;

- $\quad$ iron $6 \%$ EDDHA chelate;

- trisodium hydroxyethyl ethylenediamine triacetic acid (HEDTA) chelate $\left(\mathrm{Na}_{3} \mathrm{C}_{10} \mathrm{H}_{15} \mathrm{~N}_{2} \mathrm{O}_{7}\right)$;

- 2-(N-morpholino)ethanesulfonic acid (MES) as a biological $\mathrm{pH}$ buffer.

Each nutrient was added to deionized water (container $~ 80 \%$ full). For the Hoagland solution, nutrients were added from premixed stock solutions. For the Hopkins SNS solution, nutrients were added to containers from a premixed stock solution except for (1) $\mathrm{Ca}$ and $\mathrm{Mg}$, which were solids, and (2) $\mathrm{P}, \mathrm{S}$, and $\mathrm{Cl}$, which were supplied as concentrated acids, diluted in $\sim 200 \mathrm{~mL}$ of deionized water for each replicate, and then added to each container individually. In the Hopkins SNS solution, nutrients were added in the following order: HEDTA, N, K, Zn, Mn, Cu, B, Mo, P, S, Cl, MES, Ca, and Mg (in some cases, the order is important as a function of chemical reactions). After nutrients were added, the containers were brought to volume (within $\sim 1 \mathrm{~cm}$ of the top). On the day of mixing, an equal amount of acetic acid ( 0.03 moles) was added to all of the " $\mathrm{H}$ " solution treatments to initially adjust $\mathrm{pH}$ to 6.3 or lower (not added to the Hoagland solution (ctrl)). At $35 \mathrm{~d}$, it was suspected that the nutrient solutions needed to be replenished. This was done at $100 \%$ of the original rate for all nutrients in all treatments, with the exception of $\mathrm{Mn}$ and $\mathrm{Ca}$ in Treatments 2-6. Mn was added at a $40 \%$ rate at $35 \mathrm{~d}$, and Ca was not added due to a temporary chemical supply shortage. Once obtained, at $48 \mathrm{~d}, \mathrm{Mn}$ and Ca were replenished with the remaining $60 \%$ and $100 \%$, respectively. All nutrient additions were performed by adding the nutrient directly to each container without emptying the old solution.

The $\mathrm{pH}$ was adjusted to 5.2-6.5 in all but Treatments 1 and 2, three times weekly. The $\mathrm{pH}$ was lowered with acetic acid or $\mathrm{HCl}$ (Table 1) when it climbed too high and raised with solid sodium hydroxide $(\mathrm{NaOH})$ when it dropped too low.

\subsection{Growth and Harvesting}

The number of healthy plants was thinned down to one plant per fitting in five fittings per container within $13 \mathrm{~d}$ of planting. Three plants were sampled from each container at $20 \mathrm{~d}$ after planting for further thinning and nutrient analysis. Plants were harvested with separate shoots and roots by cutting the base of the stem immediately above the fitting and cutting the roots off just below the fitting (the minimal plant material interwoven into the mesh was not included in the dry weight and nutrient analysis measurements). Roots were rapidly rinsed by plunging three times in deionized water to remove any loose surface-bound nutrients. At $32 \mathrm{~d}$, one of the remaining two plants was harvested using a similar procedure as above. All remaining plants were harvested at $53 \mathrm{~d}$ (one plant in a replicate from Treatment 5 died early at $48 \mathrm{~d}$ due to roots breaking off from the bottom of the fitting). For the $53 \mathrm{~d}$ harvest, leaves were separated from stems. For all harvests, plant tissue was dried at $80^{\circ} \mathrm{C}$ until weights did not change over a $24 \mathrm{~h}$ period. Material from the $53 \mathrm{~d}$ harvest was partially dried under a fan in the growth chamber prior to being placed in the drying oven. These three harvest dates were chosen as growth differences were becoming evident and because growth was great enough to analyze nutrient contents and find any statistical differences that were present, if any. At $53 \mathrm{~d}$, the study was ended as the objectives had been achieved and because the plants were outgrowing their containers and thus at increased risk of the root container and/or growth chamber beginning to be the limiting factor for growth.

Visual ratings for shoots and roots were recorded at 20,28, and $53 \mathrm{~d}$ using a scale of $0-5$, with 0 being a dead plant and 5 being the relatively healthiest plant in the study at that time. Stem widths were measured with calipers. Plant height was measured at the top 
of the longest shoot at the $32 \mathrm{~d}$ harvest and at the naturally setting plant height at the $53 \mathrm{~d}$ harvest.

Dried plant material from the $20 \mathrm{~d}$ harvest and dried leaves from the $53 \mathrm{~d}$ harvest were ground to pass a 60 -mesh $(0.25 \mathrm{~mm})$ screen and analyzed for nutrient content by the Brigham Young University-Environmental Analytical Laboratory (BYU_EAL; https:/ / pws.byu.edu/eal; accessed on 10 March 2021). As the trends were generally similar between these harvests, the $32 \mathrm{~d}$ harvest was not analyzed to conserve resources. The plant tissue was digested via nitric acid-hydrogen peroxide microwave digestion (EPA Method 3052, using an Ethos EZ microwave, Milestone, Shelton, CT, USA), followed by ICP-optical emission spectroscopy (OES) (iCAP 7400, Thermo Electron, Madison, WI, USA) analysis to determine the concentrations of $\mathrm{Na}$ and all nutrients besides $\mathrm{N}$ for each experimental unit. For N, an approximately equal amount of each replicate within a treatment was consolidated, and this composite sample was tested for total $\mathrm{N}$, as determined by combustion (Vario EL Cube, Elementar, Langenselbold, Germany).

Statistical analysis was performed by analysis of variance (ANOVA), with differences between means determined in $\mathrm{R}[44,45]$ by the Benjamini and Hochberg pairwise comparison method. A $p$-value of 0.05 was used as the critical value to determine statistical significance.

\section{Results}

The data presented in this study, as well as statistical analysis outputs, are openly available in a GitHub repository. Data can be found here: https://github.com/dcole9 /Hydroponic_Soybean_Data (accessed on 10 March 2021).

\subsection{Growth}

There were no statistical differences between treatments for shoot visual ratings at $28 \mathrm{~d}$ (Table 3), shoot height and stem width at $32 \mathrm{~d}$ (Table 4), root biomass at 32 and $53 \mathrm{~d}$ (Figure 1), and height and shoot visual ratings at $53 \mathrm{~d}$ (Table 5). However, there were significant differences for shoot visual rating at $20 \mathrm{~d}$ (Table 3), root visual rating and stem width at $53 \mathrm{~d}$ (Table 5), and shoot biomass at 32 and $53 \mathrm{~d}$ (Figure 1).

There were no statistically significant growth differences between Treatments 1 (ctrl) and $2(\mathrm{H})$ (Tables 3-5; Figure 1). Treatment H produced plants that were visually similar (Figure 2) to plants from treatment ctrl. Note that the slight chlorosis of the lower leaves, seen in Figure 2, was present in all replicates of both treatments, and this is a natural response as plants mature and begin transporting mobile nutrients (e.g., N, P, and K) from older, less-efficient leaves to be repurposed in the reproductive tissues. Treatment $3, \mathrm{H}-\mathrm{HCl}$, also showed no statistical differences in growth with treatment ctrl or treatment $\mathrm{H}$.

Adjusting $\mathrm{pH}$ with acetic acid instead of $\mathrm{HCl}$ appeared to have a deleterious effect on several growth parameters. Treatment $4, \mathrm{H}-\mathrm{AA}$, had numerically lower values for all growth measurements, except plant height and shoot rating, than all other treatments. This treatment had roots that appeared to be damaged (Table 5), reduced stem width (Table 5), and statistically lower shoot biomass at 32 and $53 \mathrm{~d}$ (Figure 1), with trends towards lower root biomass (Figure 1) when compared to treatments ctrl and $\mathrm{H}$.

The other acetic acid treatments, which had reduced $\mathrm{Ca}$ and $\mathrm{Mg}(\mathrm{H}-\mathrm{Ca} / \mathrm{Mg}$ and $\mathrm{H}-$ $\mathrm{Ca} / \mathrm{Mg}+\mathrm{Mn}$ ), trended towards having healthier plants than H-AA (Tables 3-5; Figure 1). All of these acetic acid treatments were statistically equivalent with each other, with the exception of shoot biomass at $32 \mathrm{~d}$ (Figure 1), and $\mathrm{H}-\mathrm{Ca} / \mathrm{Mg}$ was visually superior at $20 \mathrm{~d}$ (Table 3). Treatment 7 (Table 1), with acetate as the Ca source, failed completely as the plants were massively stunted and sickly by $20 \mathrm{~d}$. 
$32 \mathrm{~d}$
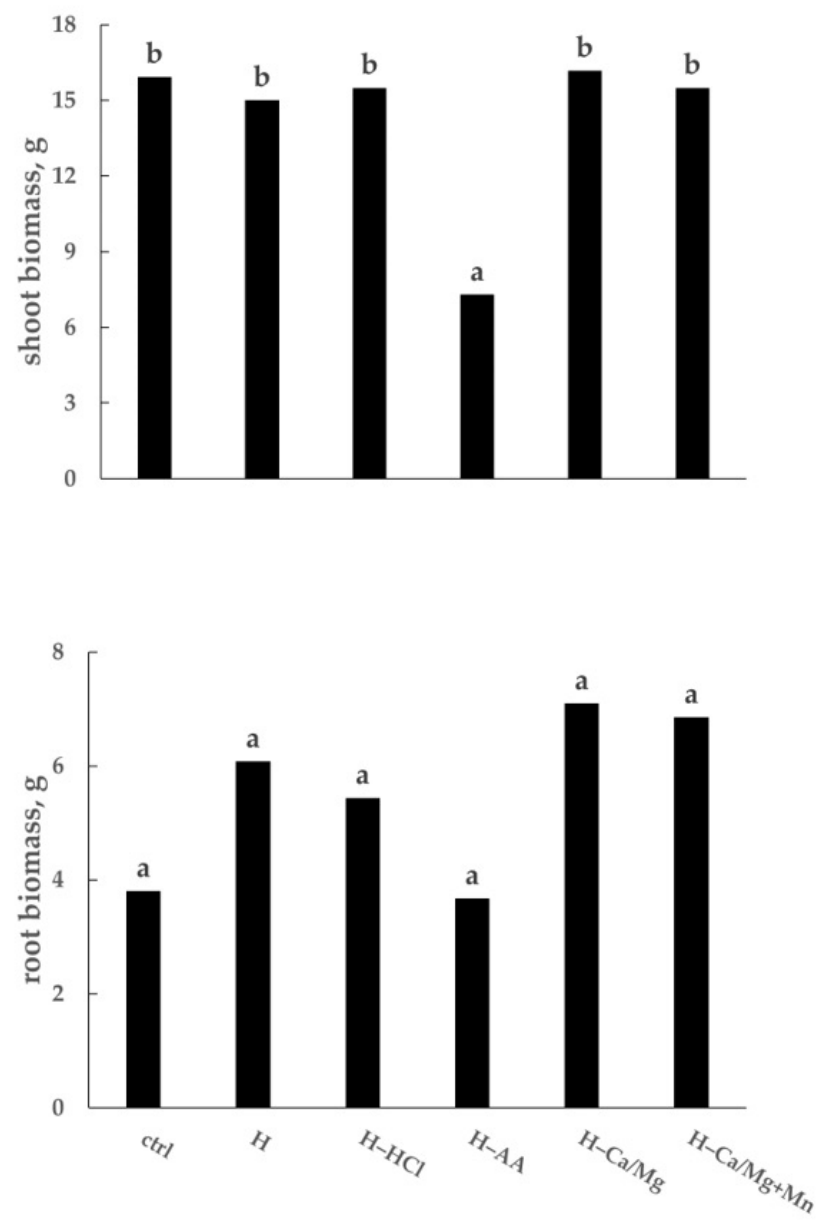

$53 \mathrm{~d}$
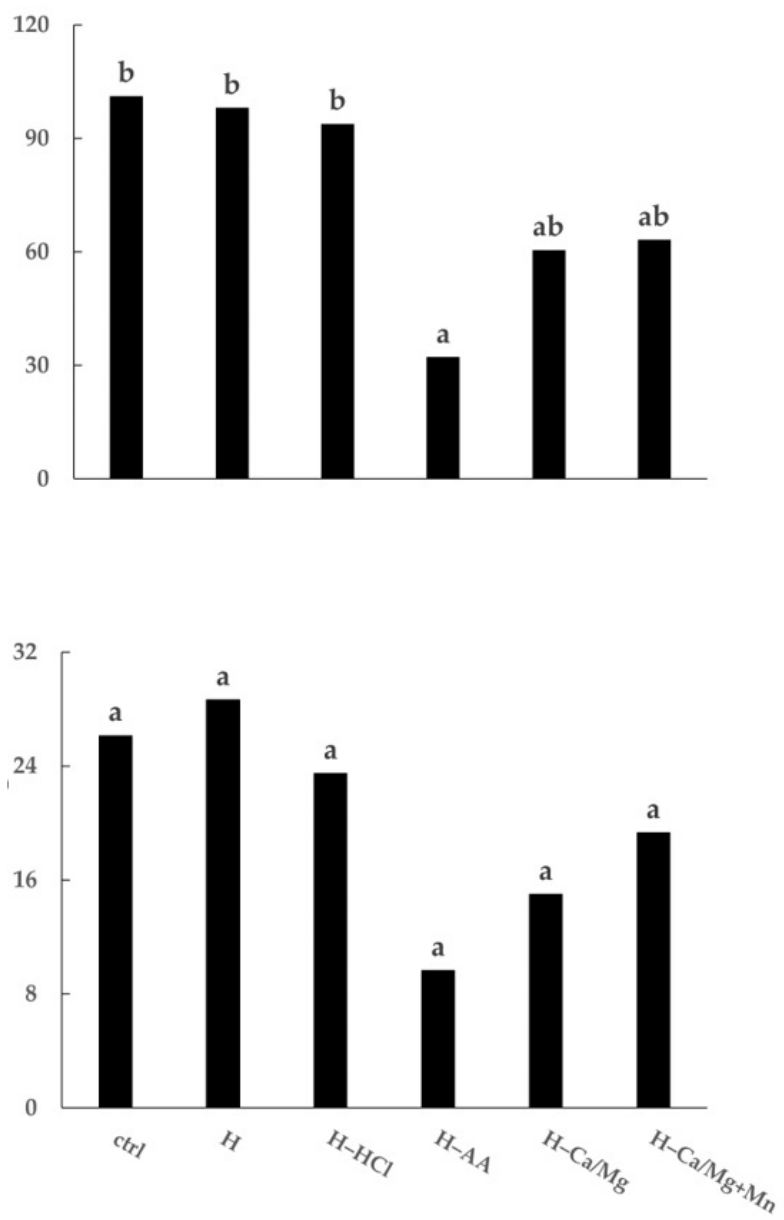

Figure 1. Soybean root and shoot biomass at 32 (growth stage V8+) and $53 \mathrm{~d}$ (growth stage R1-R2) after planting for a hydroponic nutrition study. "ctrl" = Hoagland solution; " $\mathrm{H}^{\prime}$ = Hopkins single-nutrient source (SNS) solution; "HCl" and "AA" indicate that $\mathrm{pH}$ was adjusted in-season with hydrochloric or acetic acid, respectively; "-Ca/ $\mathrm{Mg}$ " = reductions of $21 \%$ for $\mathrm{Ca}$ and $73 \%$ for $\mathrm{Mg}$, as compared to the full strength $\mathrm{H}$ solution; "+ $\mathrm{Mn}$ " $=25 \%$ increase in concentration compared to full-strength $\mathrm{H}$ solution, also adjusted with AA (Table 1). Treatments within a single graph (quadrant) sharing the same letter are not statistically different $(p=0.05 ; \mathrm{n}=3)$.

Table 3. Soybean canopy visual ratings (scale of 0 to 5 , with $0=$ dead and $5=$ healthy green) at 20 (growth stage V4-V6) and $28 \mathrm{~d}$ (growth stage V6+) after planting for a hydroponic nutrition study.

\begin{tabular}{cccccc}
\hline Treatment Number & Treatment ID & \multicolumn{2}{c}{$\mathbf{2 0} \mathbf{d}$} & \multicolumn{2}{c}{$\mathbf{2 8 ~ d}$} \\
\hline 1 & $\mathrm{ctrl}$ & 3.3 & $\mathrm{a}$ & 4.0 & $\mathrm{a}$ \\
2 & $\mathrm{H}$ & 3.7 & $\mathrm{ab}$ & 4.0 & $\mathrm{a}$ \\
3 & $\mathrm{H}-\mathrm{HCl}$ & 3.5 & $\mathrm{ab}$ & 4.0 & $\mathrm{a}$ \\
4 & $\mathrm{H}-\mathrm{AA}$ & 3.5 & $\mathrm{ab}$ & 3.4 & $\mathrm{a}$ \\
5 & $\mathrm{H}-\mathrm{Ca} / \mathrm{Mg}$ & 4.8 & $\mathrm{c}$ & 4.5 & $\mathrm{a}$ \\
6 & $\mathrm{H}-\mathrm{Ca} / \mathrm{Mg}+\mathrm{Mn}$ & 4.3 & $\mathrm{bc}$ & 3.8 & $\mathrm{a}$ \\
\hline
\end{tabular}

"ctrl" = Hoagland solution; "H" = Hopkins single-nutrient source (SNS) solution; "HCl" and "AA" indicate that $\mathrm{pH}$ was adjusted in-season with hydrochloric or acetic acid, respectively; "-Ca/Mg" = reductions of $21 \%$ for $\mathrm{Ca}$ and $73 \%$ for $\mathrm{Mg}$, as compared to the full strength $\mathrm{H}$ solution; " $+\mathrm{Mn}^{\prime \prime}=25 \%$ increase in concentration compared to full-strength $\mathrm{H}$ solution, also adjusted with AA (Table 1). Values within a column sharing the same letter(s) are not significantly different from one another $(p=0.05 ; \mathrm{n}=3)$. 
Table 4. Soybean height and stem width at $32 \mathrm{~d}$ (growth stage V8+) after planting for a hydroponic nutrition study.

\begin{tabular}{cccccc}
\hline Treatment Number & Treatment ID & & Height, $\mathbf{c m}$ & \multicolumn{2}{c}{ Stem Width, cm } \\
\hline 1 & ctrl & 31 & $\mathrm{a}$ & 0.81 \\
2 & $\mathrm{H}$ & 34 & $\mathrm{a}$ & 0.86 \\
3 & $\mathrm{H}-\mathrm{HCl}$ & 29 & $\mathrm{a}$ & 0.76 \\
4 & $\mathrm{H}-\mathrm{AA}$ & 31 & $\mathrm{a}$ & 0.66 & $\mathrm{a}$ \\
5 & $\mathrm{H}-\mathrm{Ca} / \mathrm{Mg}$ & 41 & $\mathrm{a}$ & 0.81 & $\mathrm{a}$ \\
6 & $\mathrm{H}-\mathrm{Ca} / \mathrm{Mg}+\mathrm{Mn}$ & 30 & $\mathrm{a}$ & 0.84 & $\mathrm{a}$ \\
\hline
\end{tabular}

"ctrl" = Hoagland solution; " $\mathrm{H}^{\prime \prime}=$ Hopkins single-nutrient source (SNS) solution; " $\mathrm{HCl}^{\prime \prime}$ and " $\mathrm{AA}^{\prime \prime}$ indicate that $\mathrm{pH}$ was adjusted in-season with hydrochloric or acetic acid, respectively; "-Ca/ $\mathrm{Mg}$ " $=$ reductions of $21 \%$ for $\mathrm{Ca}$ and $73 \%$ for $\mathrm{Mg}$, as compared to the full-strength $\mathrm{H}$ solution; " $+\mathrm{Mn}^{\prime \prime}=25 \%$ increase in concentration compared to full strength $\mathrm{H}$ solution, also adjusted with AA (Table 1). Height indicated is from the top of the fitting to the tip of the longest shoot. Values within a column sharing the same letter(s) are not significantly different from one another $(p=0.05 ; \mathrm{n}=3)$.

Table 5. Soybean height, stem width, and shoot and root visual ratings (scale of 0 to 5 , with $0=$ dead and 5 = relatively healthiest shoot/root) at $53 \mathrm{~d}$ (growth stage R1-R2) after planting for a hydroponic nutrition study.

\begin{tabular}{cclllccccc}
\hline Treatment Number & Treatment ID & \multicolumn{2}{l}{ Height, cm } & \multicolumn{2}{l}{ Stem Width, cm } & Shoot Rating & Root Rating \\
\hline 1 & $\mathrm{ctrl}$ & 75 & $\mathrm{a}$ & 1.59 & $\mathrm{~b}$ & 4.6 & $\mathrm{a}$ & 5.0 & $\mathrm{~b}$ \\
2 & $\mathrm{H}$ & 63 & $\mathrm{a}$ & 1.63 & $\mathrm{~b}$ & 4.2 & $\mathrm{a}$ & 5.0 & $\mathrm{~b}$ \\
3 & $\mathrm{H}-\mathrm{HCl}$ & 59 & $\mathrm{a}$ & 1.39 & $\mathrm{ab}$ & 4.0 & $\mathrm{a}$ & 4.9 & $\mathrm{~b}$ \\
4 & $\mathrm{H}-\mathrm{AA}$ & 57 & $\mathrm{a}$ & 0.98 & $\mathrm{a}$ & 3.4 & $\mathrm{a}$ & 3.3 & $\mathrm{a}$ \\
5 & $\mathrm{H}-\mathrm{Ca} / \mathrm{Mg}$ & 81 & $\mathrm{a}$ & 1.31 & $\mathrm{ab}$ & 3.8 & $\mathrm{a}$ & 4.1 & $\mathrm{ab}$ \\
6 & $\mathrm{H}-\mathrm{Ca} / \mathrm{Mg}+\mathrm{Mn}$ & 56 & $\mathrm{a}$ & 1.28 & $\mathrm{ab}$ & 3.6 & $\mathrm{a}$ & 3.9 & $\mathrm{ab}$ \\
\hline
\end{tabular}

"ctrl" = Hoagland solution; " $\mathrm{H}^{\prime \prime}=$ Hopkins single-nutrient source (SNS) solution; " $\mathrm{HCl}^{\prime \prime}$ and " $\mathrm{AA}^{\prime \prime}$ indicate that $\mathrm{pH}$ was adjusted in-season with hydrochloric or acetic acid, respectively; "-Ca/Mg" = reductions of $21 \%$ for $\mathrm{Ca}$ and $73 \%$ for $\mathrm{Mg}$, as compared to the full-strength $\mathrm{H}$ solution; " $+\mathrm{Mn}^{\prime \prime}=25 \%$ increase in concentration compared to full-strength $\mathrm{H}$ solution, also adjusted with AA (Table 1). Height indicated is the natural setting plant height. Values within a column sharing the same letter(s) are not significantly different from one another $(p=0.05 ; \mathrm{n}=3)$.
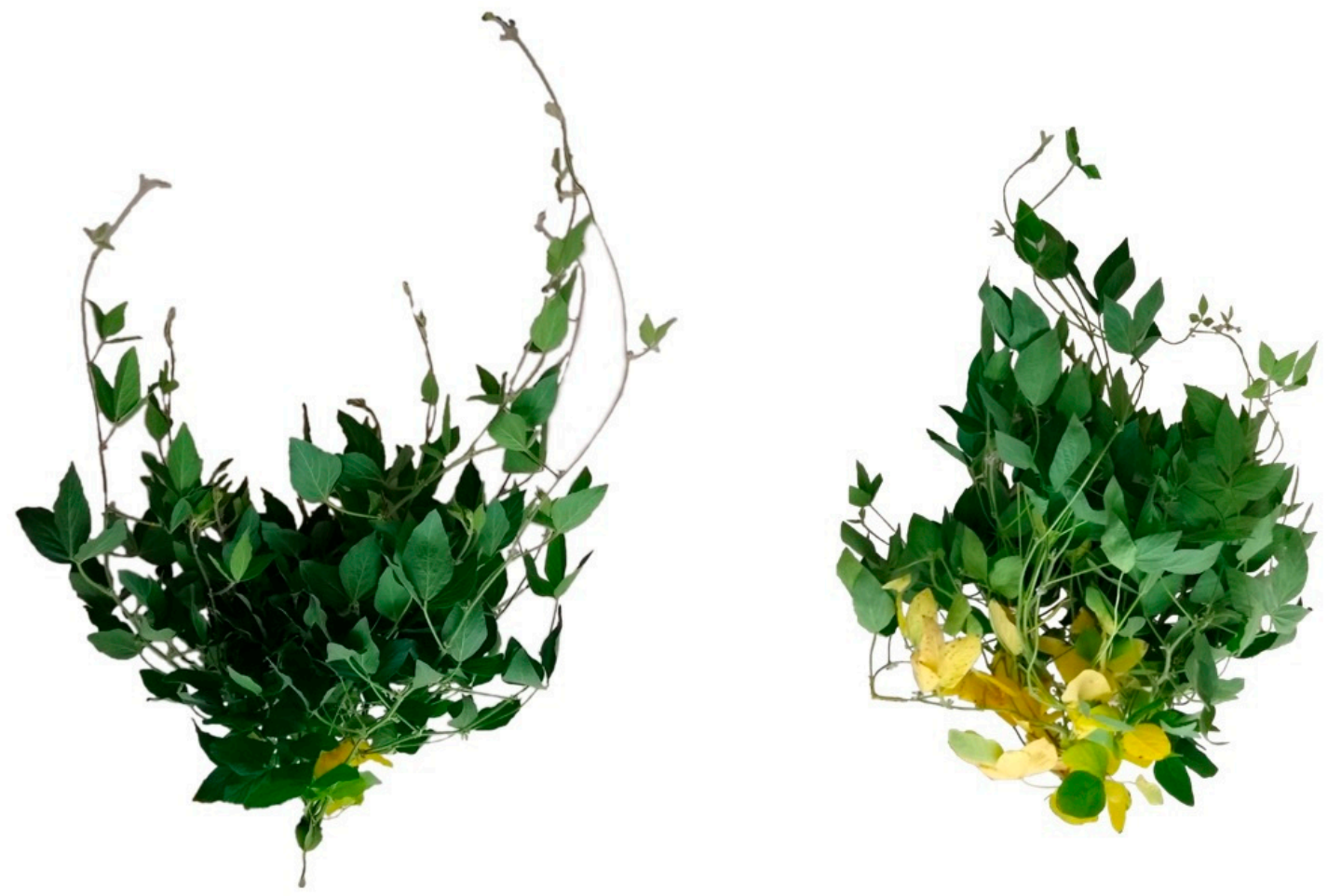

Figure 2. Soybean plants at $53 \mathrm{~d}$ (growth stage R1-R2) after planting for a hydroponic nutrition study (treatment ctrl on the left, treatment $\mathrm{H}$ on the right; see Table 1)). Plants were cut at the base of the stem and held upside down when the pictures were taken to show the length of the plant. Note that the slight chlorosis of the lower leaves is a natural response in soybean as plants mature and begin transporting mobile nutrients (e.g., N, P, and K) from older, less-efficient leaves to be repurposed in the reproductive tissues. This response was present in all three replicates of both treatments. Pictures are not to scale. 


\subsection{Nutrient Concentrations}

The concentration of nutrients in the shoots was impacted by the treatments. There were statistical differences across treatments for most of the macronutrients (Table 6) and several of the micronutrients (Table 7).

Table 6. Soybean shoot macronutrient concentrations at 20 (growth stage V4-V6) and 53 (growth stage R1-R2) d after planting for a hydroponic nutrition study.

\begin{tabular}{|c|c|c|c|c|c|c|c|c|c|c|c|c|c|}
\hline & \multicolumn{2}{|c|}{ Treatment } & $\mathbf{N}$ & \multicolumn{2}{|c|}{$\mathbf{P}$} & \multicolumn{2}{|c|}{$\mathbf{K}$} & \multicolumn{2}{|c|}{$\mathbf{S}$} & \multicolumn{2}{|c|}{ Ca } & \multicolumn{2}{|c|}{ Mg } \\
\hline & Number & ID & \multicolumn{11}{|c|}{$\mathrm{g} \mathrm{kg}^{-1}$} \\
\hline \multirow{6}{*}{$20 \mathrm{~d}$} & 1 & ctrl & 51.9 & 12.5 & $c$ & 30.1 & c & 3.4 & $\mathrm{ab}$ & 24.0 & $\mathrm{~d}$ & 5.3 & $b$ \\
\hline & 2 & $\mathrm{H}$ & 62.3 & 11.0 & $c$ & 23.7 & $b$ & 3.8 & $\mathrm{ab}$ & 15.9 & $\mathrm{~b}$ & 6.2 & $b$ \\
\hline & 3 & $\mathrm{H}-\mathrm{HCl}$ & 62.8 & 10.9 & $c$ & 24.5 & $\mathrm{~b}$ & 4.1 & $\mathrm{~b}$ & 20.1 & $\mathrm{c}$ & 5.3 & $\mathrm{~b}$ \\
\hline & 4 & $\mathrm{H}-\mathrm{AA}$ & 61.3 & 5.1 & $\mathrm{a}$ & 18.8 & $\mathrm{a}$ & 3.0 & $\mathrm{a}$ & 12.3 & $\mathrm{a}$ & 5.8 & $b$ \\
\hline & 5 & $\mathrm{H}-\mathrm{Ca} / \mathrm{Mg}$ & 66.7 & 7.7 & $\mathrm{~b}$ & 23.9 & $\mathrm{~b}$ & 3.5 & $\mathrm{~b}$ & 16.9 & $\mathrm{bc}$ & 3.8 & a \\
\hline & 6 & $\mathrm{H}-\mathrm{Ca} / \mathrm{Mg}+\mathrm{Mn}$ & 66.0 & 8.9 & $\mathrm{~b}$ & 24.7 & $b$ & 3.9 & $\mathrm{~b}$ & 18.6 & $\mathrm{bc}$ & 3.8 & $\mathrm{a}$ \\
\hline \multicolumn{3}{|c|}{ typical observed field values at early growth stage [42] } & $35-55$ & \multicolumn{2}{|c|}{$3.0-6.0$} & \multicolumn{2}{|c|}{$17-25$} & \multicolumn{2}{|c|}{$3.0-8.0$} & \multicolumn{2}{|c|}{$11-22$} & \multicolumn{2}{|c|}{$3.0-6.0$} \\
\hline \multirow{6}{*}{$53 \mathrm{~d}$} & 1 & ctrl & 47.5 & 3.4 & $\mathrm{a}$ & 18.1 & $\mathrm{bc}$ & 2.0 & $\mathrm{a}$ & 22.4 & $\mathrm{a}$ & 5.2 & $a b$ \\
\hline & 2 & $\mathrm{H}$ & 36.5 & 3.0 & $\mathrm{a}$ & 12.9 & $\mathrm{a}$ & 2.5 & $\mathrm{a}$ & 21.9 & $\mathrm{a}$ & 5.8 & bc \\
\hline & 3 & $\mathrm{H}-\mathrm{HCl}$ & 34.7 & 2.8 & a & 14.0 & $\mathrm{ab}$ & 2.5 & $\mathrm{a}$ & 22.7 & $\mathrm{a}$ & 4.6 & $\mathrm{ab}$ \\
\hline & 4 & $\mathrm{H}-\mathrm{AA}$ & 46.7 & 6.5 & $\mathrm{~b}$ & 18.0 & $\mathrm{bc}$ & 3.3 & $\mathrm{a}$ & 18.5 & $\mathrm{a}$ & 7.1 & c \\
\hline & 5 & $\mathrm{H}-\mathrm{Ca} / \mathrm{Mg}$ & 48.1 & 4.8 & $a b$ & 19.0 & $\mathrm{c}$ & 2.8 & $\mathrm{a}$ & 22.1 & $\mathrm{a}$ & 4.1 & $a b$ \\
\hline & 6 & $\mathrm{H}-\mathrm{Ca} / \mathrm{Mg}+\mathrm{Mn}$ & 38.2 & 4.6 & $a b$ & 16.2 & $a b c$ & 2.6 & $\mathrm{a}$ & 24.3 & $\mathrm{a}$ & 3.5 & $\mathrm{a}$ \\
\hline \multicolumn{3}{|c|}{ typical observed field values at pod set growth stage [42] } & $40-55$ & \multicolumn{2}{|c|}{$2.5-5.0$} & \multicolumn{2}{|c|}{$17-25$} & \multicolumn{2}{|c|}{$2.0-3.5$} & \multicolumn{2}{|c|}{$3.5-20$} & \multicolumn{2}{|c|}{$2.5-10$} \\
\hline
\end{tabular}

"ctrl" = Hoagland solution; "H" = Hopkins single-nutrient source (SNS) solution; "HCl" and "AA" indicate that pH was adjusted in-season with hydrochloric or acetic acid, respectively; "-Ca/ $\mathrm{Mg}$ " = reductions of $21 \%$ for Ca and $73 \%$ for $\mathrm{Mg}$, as compared to the full-strength $\mathrm{H}$ solution; " $+\mathrm{Mn}^{\prime \prime}=25 \%$ increase in concentration compared to full-strength H solution, also adjusted with AA (Table 1 ). Values within a column sharing the same letter(s) are not significantly different from one another $(p=0.05 ; \mathrm{n}=3)$. No statistics were calculated for $\mathrm{N}$ as sampling was not replicated. Known concentrations for field-grown soybean are listed in italic font at the bottom row for each sampling date [40].

Table 7. Soybean shoot micronutrient and sodium concentrations at 20 (growth stage V4-V6) and 53 (growth stage (R1-R2) $\mathrm{d}$ after planting for a hydroponic nutrition study.

\begin{tabular}{|c|c|c|c|c|c|c|c|c|c|c|c|c|c|c|c|c|c|c|}
\hline & \multicolumn{2}{|r|}{ Treatment } & \multicolumn{2}{|c|}{$\mathrm{Zn}$} & \multicolumn{2}{|c|}{ Mn } & \multicolumn{2}{|c|}{$\mathrm{Fe}$} & \multicolumn{2}{|c|}{$\mathrm{Cu}$} & \multicolumn{2}{|c|}{ B } & \multicolumn{2}{|c|}{ Mo } & \multicolumn{2}{|c|}{$\mathrm{Na}$} & \multicolumn{2}{|c|}{$\mathrm{Ni}$} \\
\hline & Number & ID & \multicolumn{16}{|c|}{$\mathrm{mg} \cdot \mathrm{kg}^{-1}$} \\
\hline \multirow{6}{*}{$20 \mathrm{~d}$} & 1 & ctrl & 32 & $\mathrm{~b}$ & 106 & $\mathrm{a}$ & 113 & $\mathrm{ab}$ & 2.1 & $\mathrm{a}$ & 32 & $\mathrm{a}$ & 8.1 & $\mathrm{~b}$ & 57 & $\mathrm{a}$ & 0.7 & a \\
\hline & 2 & $\mathrm{H}$ & 26 & $\mathrm{ab}$ & 77 & a & 110 & $a b$ & 2.3 & $\mathrm{a}$ & 40 & $\mathrm{~b}$ & 8.3 & $\mathrm{~b}$ & 100 & a & 0.7 & $\mathrm{a}$ \\
\hline & 3 & $\mathrm{H}-\mathrm{HCl}$ & 33 & $\mathrm{~b}$ & 113 & a & 147 & $\mathrm{c}$ & 4.0 & $\mathrm{a}$ & 35 & $a b$ & 11.3 & $\mathrm{~cd}$ & 55 & a & 1.5 & a \\
\hline & 4 & $\mathrm{H}-\mathrm{AA}$ & 24 & $\mathrm{a}$ & 87 & a & 85 & $\mathrm{a}$ & 2.1 & $\mathrm{a}$ & 49 & c & 5.3 & $\mathrm{a}$ & 98 & a & 0.5 & a \\
\hline & 5 & $\mathrm{H}-\mathrm{Ca} / \mathrm{Mg}$ & 30 & $\mathrm{ab}$ & 71 & a & 109 & $a b$ & 2.2 & $\mathrm{a}$ & 41 & $\mathrm{~b}$ & 9.8 & $\mathrm{bc}$ & 82 & a & $0.3^{+}$ & - \\
\hline & 6 & $\mathrm{H}-\mathrm{Ca} / \mathrm{Mg}+\mathrm{Mn}$ & 29 & $\mathrm{ab}$ & 78 & a & 127 & $\mathrm{bc}$ & 2.3 & $\mathrm{a}$ & 38 & $a b$ & 11.9 & $\mathrm{~d}$ & 79 & $\mathrm{a}$ & 0.7 & a \\
\hline \multicolumn{3}{|c|}{ typical observed field values at early growth stage [42] } & \multicolumn{2}{|c|}{$20-86$} & \multicolumn{2}{|c|}{$23-133$} & \multicolumn{2}{|c|}{$45-300$} & \multicolumn{2}{|c|}{$5-15$} & \multicolumn{2}{|c|}{$22-55$} & \multicolumn{2}{|c|}{$1-10$} & \multicolumn{2}{|c|}{-} & \multicolumn{2}{|c|}{ - } \\
\hline \multirow{6}{*}{$53 \mathrm{~d}$} & 1 & ctrl & 15 & $\mathrm{a}$ & 75 & a & 112 & $\mathrm{a}$ & 2.5 & $a b$ & 58 & $\mathrm{a}$ & 5.0 & $\mathrm{a}$ & 37 & $\mathrm{a}$ & 0.7 & a \\
\hline & 2 & $\mathrm{H}$ & 57 & c & 92 & $a b$ & 149 & $\mathrm{a}$ & 3.1 & $\mathrm{~b}$ & 61 & $\mathrm{a}$ & 2.5 & $\mathrm{a}$ & 16 & $\mathrm{a}$ & 1.1 & a \\
\hline & 3 & $\mathrm{H}-\mathrm{HCl}$ & 56 & c & 85 & $a b$ & 131 & $\mathrm{a}$ & 3.0 & $\mathrm{~b}$ & 47 & $\mathrm{a}$ & 2.0 & $\mathrm{a}$ & 30 & $\mathrm{a}$ & 0.7 & a \\
\hline & 4 & $\mathrm{H}-\mathrm{AA}$ & 36 & b & 97 & $a b$ & 106 & $\mathrm{a}$ & 1.5 & a & 68 & $\mathrm{a}$ & 5.9 & $\mathrm{a}$ & 14 & $\mathrm{a}$ & 0.8 & $\mathrm{a}$ \\
\hline & 5 & $\mathrm{H}-\mathrm{Ca} / \mathrm{Mg}$ & 51 & c & 118 & $\mathrm{bc}$ & 173 & $\mathrm{a}$ & 2.6 & $a b$ & 65 & $\mathrm{a}$ & 4.9 & $\mathrm{a}$ & 14 & $\mathrm{a}$ & 0.7 & $\mathrm{a}$ \\
\hline & 6 & $\mathrm{H}-\mathrm{Ca} / \mathrm{Mg}+\mathrm{Mn}$ & 49 & bc & 137 & c & 154 & $\mathrm{a}$ & 2.4 & $\mathrm{ab}$ & 61 & $\mathrm{a}$ & 2.9 & $\mathrm{a}$ & 15 & $\mathrm{a}$ & 1.1 & $\mathrm{a}$ \\
\hline typica & bserved field & at pod set growth stage [42] & \multicolumn{2}{|c|}{$20-50$} & \multicolumn{2}{|c|}{$20-100$} & \multicolumn{2}{|c|}{$50-350$} & \multicolumn{2}{|c|}{ 10-30 } & & & \multicolumn{2}{|c|}{$1-5$} & \multicolumn{2}{|c|}{ - } & & \\
\hline
\end{tabular}

${ }^{+}$One replicate was below detectable levels and, thus, not included in statistical analysis. The average of the other two replicates is reported. "ctrl" = Hoagland solution; "H" = Hopkins single-nutrient source (SNS) solution; "HCl" and "AA" indicate that pH was adjusted in-season with hydrochloric or acetic acid, respectively; "-Ca/ $\mathrm{Mg}$ " = reductions of $21 \%$ for $\mathrm{Ca}$ and $73 \%$ for $\mathrm{Mg}$, as compared to the full strength $\mathrm{H}$ solution; "+Mn" $=25 \%$ increase in concentration compared to full-strength H solution, also adjusted with AA (Table 1 ). Values within a column sharing the same letter(s) are not significantly different from one another $(p=0.05 ; \mathrm{n}=3)$. Known concentrations for field-grown soybean are listed in italic font at the bottom row for each sampling date [40].

\subsubsection{Macronutrients}

At $20 \mathrm{~d}$ after planting, P concentrations were generally higher than what is typically observed under field conditions [40] (Table 6). The ctrl, $\mathrm{H}$, and $\mathrm{H}-\mathrm{HCl}$ treatments were 2-4 times higher than the typical observed field value and significantly higher than the treatments with $\mathrm{pH}$ adjusted with acetic acid. The use of acetic acid resulted in reduced $\mathrm{P}$ concentration at this stage, but the effect was lessened when $\mathrm{Ca}$ and $\mathrm{Mg}$ concentrations in the nutrient solutions were decreased. By $53 \mathrm{~d}$, this effect was largely reversed, with 
$\mathrm{H}-\mathrm{AA}$ significantly higher in $\mathrm{P}$ concentration than the ctrl, $\mathrm{H}$, and $\mathrm{H}-\mathrm{HCl}$ treatments. This is likely related to the dilution effect caused by differences in growth, with $\mathrm{P}$ concentrations approximately inversely proportional to shoot growth (Figure 1). Despite being relatively high at $20 \mathrm{~d}, \mathrm{P}$ concentrations were generally within the typical observed field value range by $53 \mathrm{~d}$ (Table 6) [40]. For the two treatments without $\mathrm{pH}$ adjustment, the ctrl had higher $\mathrm{P}$ concentrations at 20 and $53 \mathrm{~d}$ than the $\mathrm{H}$ solution (Table 6). This is reflective of nutrient solutions, with the ctrl having 1.3 times more $\mathrm{P}$ than solution $\mathrm{H}$ (Table 2).

Similarly, the ctrl had 1.5 times the $\mathrm{K}$ in nutrient solution than solution $\mathrm{H}$ (Table 2) and, as with $\mathrm{P}$, this was reflective with the ctrl having higher $\mathrm{K}$ at 20 and $53 \mathrm{~d}$ than treatment $\mathrm{H}$ (Table 6). At $20 \mathrm{~d}$, the $\mathrm{K}$ concentration in the shoot tissue of the ctrl treatment was slightly higher than typically observed field values [40]. The other treatments were significantly lower and in a more typical range. The H-AA treatment with poor growth (Tables 3-5; Figure 1) had significantly less $K$ concentration in the shoots than all other treatments (Table 6) at $20 \mathrm{~d}$. By $53 \mathrm{~d}$, treatments $\mathrm{H}, \mathrm{H}-\mathrm{HCl}$, and $\mathrm{H}-\mathrm{Ca} / \mathrm{Mg}+\mathrm{Mn}$ were below the typical observed field value range for $\mathrm{K}$, with solution $\mathrm{H}$ being significantly lower in shoot $\mathrm{K}$ than the ctrl and some other treatments (Table 6).

At both the 20 and $53 \mathrm{~d}$ harvests, $\mathrm{S}$ concentrations were within the typical observed field value range [40] (Table 6). The H-AA treatment had significantly less shoot $\mathrm{S}$ concentration than the other $\mathrm{pH}$-adjusted treatments. There were no differences between treatments at $53 \mathrm{~d}$ (Table 6), with all treatments having approximately the same $\mathrm{S}$ concentration in the nutrient solutions (Table 2).

For Ca at the $20 \mathrm{~d}$ harvest, the ctrl had slightly higher than typically observed field shoot Ca concentrations and was significantly higher than all other treatments (Table 6). This is in spite of the fact that the ctrl nutrient solution had identical $\mathrm{Ca}$ as treatments $\mathrm{H}$, $\mathrm{H}-\mathrm{HCl}$, and $\mathrm{H}-\mathrm{AA}$ (Table 2). Treatment $\mathrm{H}-\mathrm{HCl}$ had significantly higher shoot $\mathrm{Ca}$ than $\mathrm{H}$ and H-AA but, surprisingly, not statistically more than the reduced Ca treatments (Table 6). Even more surprising was that the H-AA treatment had significantly lower shoot $\mathrm{Ca}$ than all other treatments. By $53 \mathrm{~d}$, shoot Ca concentrations for all treatments except for $\mathrm{H}-\mathrm{AA}$ were higher than typically observed field values, but no statistical differences were seen between treatments (Table 6).

Shoot $\mathrm{Mg}$ concentrations were generally within a typically observed field value range for all treatments (Table 6). At $20 \mathrm{~d}$, the only differences were as expected, with lower shoot $\mathrm{Mg}$ for treatments receiving less $\mathrm{Mg}$ than the others. These continued to be relatively low at the $53 \mathrm{~d}$ harvest. Additionally, the $\mathrm{H}-\mathrm{AA}$ treatment accumulated more shoot $\mathrm{Mg}$ (again, likely due to a dilution effect) than all other treatments except $\mathrm{H}$ at the $53 \mathrm{~d}$ harvest (Table 6).

Although not replicated-making the numerical differences unsubstantiated-the trends for shoot $\mathrm{N}$ concentration at the $20 \mathrm{~d}$ harvest suggest that all treatments except the ctrl were higher than what is typically observed in field plants at a similar growth stage (Table 6). This is slightly surprising as the ctrl had 1.4 times higher $\mathrm{N}$ in solution than the $\mathrm{H}$ treatments (Table 2). By the $53 \mathrm{~d}$ harvest, this trend had mostly reversed, with $\mathrm{N}$ concentrations lower than typically observed field values for the $\mathrm{H}, \mathrm{H}-\mathrm{HCl}$, and $\mathrm{H}-\mathrm{Ca} / \mathrm{Mg}+\mathrm{Mn}$ treatments (Table 6).

\subsubsection{Micronutrients}

Despite the $\mathrm{H}$ treatment having over five times more $\mathrm{Zn}$ in the nutrient solution compared to the ctrl (Table 2), all treatments other than H-AA were similar in shoot $\mathrm{Zn}$ at $20 \mathrm{~d}$ (Table 7). The $\mathrm{H}-\mathrm{AA}$ treatment was significantly lower than the ctrl and $\mathrm{H}-\mathrm{HCl}$ treatments, although all were in a typically observed field value range (Table 7; [40]). By $53 \mathrm{~d}$, shoot $\mathrm{Zn}$ was more reflective of nutrient solution concentrations (Table 2), with the ctrl treatment significantly lower than all other treatments (Table 7). The H-AA treatment was also lower than all of the other treatments but one. At $53 \mathrm{~d}$, the shoot $\mathrm{Zn}$ concentrations for the ctrl treatment were lower than typically observed field values and possibly deficient (Table 7), even though growth seemed to be unaffected (Tables 3-5; Figure 1). In contrast, 
shoot $\mathrm{Zn}$ for the $\mathrm{H}$ treatment was slightly higher than the typically observed field value range, although unlikely to be so high as to be toxic (Table 7).

Although in the upper portion of the range, the $20 \mathrm{~d}$ shoot Mn concentrations for all treatments were within what is typically observed under field conditions for soybean at approximately the same stage of growth (Table 7). There were no differences between treatments at $20 \mathrm{~d}$, but differences appeared by the 53rd day (Table 7). Despite having slightly more $\mathrm{Mn}$ in the nutrient solution (Table 2), the ctrl treatment had significantly less $\mathrm{Mn}$ than both $\mathrm{H}$ treatments, with reduced $\mathrm{Ca}$ and $\mathrm{Mg}$ (Table 7). Not surprisingly, the treatment with higher $\mathrm{Mn}(\mathrm{H}-\mathrm{Ca} / \mathrm{Mg}+\mathrm{Mn})$ also had significantly higher shoot $\mathrm{Mn}$ than most of the treatments. Most treatments had shoot $\mathrm{Mn}$ in the typically observed field value range. However, the treatments with reduced $\mathrm{Ca}$ and $\mathrm{Mg}$, especially the treatment with added $\mathrm{Mn}$, had shoot Mn concentrations that were high (Table 7).

Although plant Fe concentrations are notoriously variable and without tight interpretation levels, Fe concentrations were within the ranges listed as typical for observed field values by Bryson et al. [40] at both the 20 and $53 \mathrm{~d}$ harvests (Table 7). Most treatments had statistically similar shoot Fe levels (Table 7) despite treatment ctrl having nearly twice as much Fe in the nutrient solutions as the other treatments. The H-AA treatment had the numerically lowest Fe concentrations at both harvests, with a significant difference at $20 \mathrm{~d}$ between it and the $\mathrm{H}-\mathrm{HCl}$ and $\mathrm{H}-\mathrm{Ca} / \mathrm{Mg}+\mathrm{Mn}$ treatments. The $\mathrm{H}-\mathrm{HCl}$ treatment had significantly higher shoot Fe than all other treatments except $\mathrm{H}-\mathrm{Ca} / \mathrm{Mg}+\mathrm{Mn}$ at $20 \mathrm{~d}$ (Table 7).

Shoot $\mathrm{Cu}$ concentrations were substantially lower than the typically observed field value range for field-grown soybean and were possibly slightly deficient for all solutions at both the 20 and $53 \mathrm{~d}$ harvests (Table 7, [40]). There were no differences between treatments at $20 \mathrm{~d}$. There were no differences at either harvest between the ctrl and the other solutions (Table 7), despite having over twice as much $\mathrm{Cu}$ in the nutrient solutions (Table 2). By the $53 \mathrm{~d}$ harvest, there was significantly less shoot $\mathrm{Cu}$ in the $\mathrm{H}-\mathrm{AA}$ compared to the $\mathrm{H}$ and $\mathrm{H}-\mathrm{HCl}$ treatments (Table 7).

At $20 \mathrm{~d}$, shoot B levels were statistically lower in the ctrl treatment than $\mathrm{H}, \mathrm{H}-\mathrm{AA}$, and $\mathrm{H}-\mathrm{Ca} / \mathrm{Mg}$ (Table 7) treatments despite the Hoagland solution having more than twice the amount of $\mathrm{B}$ in the nutrient solution (Table 2). The H-AA treatment had the highest $\mathrm{B}$ concentration and was different from all treatments (Table 7). By the $53 \mathrm{~d}$ harvest, no statistical differences were seen, but all treatments except $\mathrm{H}-\mathrm{HCl}$ were above the typically observed field value range for soybeans, and H-AA maintained the highest numerical value (Table 7).

Shoot Mo concentrations at $20 \mathrm{~d}$ were within the typically observed field value range for all treatments, but $\mathrm{H}-\mathrm{HCL}$ and $\mathrm{H}-\mathrm{Ca} / \mathrm{Mg}+\mathrm{Mn}$, which were both slightly higher than typically observed field values and significantly higher than most other treatments. Treatment H-AA had the lowest shoot Mo at this early harvest. By $53 \mathrm{~d}$, all values were in the typically observed field value range, and the earlier trends had largely disappeared. There were no differences between treatments at this harvest (Table 7), despite the ctrl having 2.5 times more Mo in the nutrient solution (Table 2).

No differences were observed for the shoot $\mathrm{Na}$ and $\mathrm{Ni}$ concentrations at either the 20 or $53 \mathrm{~d}$ harvests (Table 7).

\subsection{Solution $\mathrm{pH}$}

The $\mathrm{pH}$ showed unique trends over time for most treatments. The ctrl was initially at an average $\mathrm{pH}$, below 6.0 , and gradually rose until it was above 8.0 by $32 \mathrm{~d}$ and remained there for the duration of the study. In stark contrast, treatment $\mathrm{H}$ started at an average $\mathrm{pH}$ of 7.9 and gradually dropped until it went below 6.2 by $32 \mathrm{~d}$ and below 5.0 by $47 \mathrm{~d}$. When Ca was replenished on $48 \mathrm{~d}$, the $\mathrm{pH}$ rose above 7 due to the addition of carbonates to the solution.

The $\mathrm{H}-\mathrm{AA}$ treatment saw significant fluctuations in $\mathrm{pH}$, as it started at 7.8 and was lowered with acetic acid three times a week. On day 19, it was lowered to an acceptable 
slightly acidic range and then rose to a $\mathrm{pH}$ greater than 8 when $\mathrm{pH}$ was checked again and adjusted, $\sim 2 \mathrm{~d}$ later. This trend of $\mathrm{pH}$ spikes continued through to day 34 , with the peak of the $\mathrm{pH}$ spikes reducing to $7.0-7.9$ by day 38 . After $38 \mathrm{~d}$, $\mathrm{pH}$ fluctuations were much smaller and remained below 7 . After the addition of $\mathrm{Ca}$, the $\mathrm{pH}$ again rose, above 7 , and the spikes in $\mathrm{pH}$ continued until the end of the study. One replicate required $\mathrm{NaOH}$ to raise the $\mathrm{pH}$ at $42 \mathrm{~d}$.

The $\mathrm{H}-\mathrm{HCl}, \mathrm{H}-\mathrm{Ca} / \mathrm{Mg}$, and $\mathrm{H}-\mathrm{Ca} / \mathrm{Mg}+\mathrm{Mn}$ treatments saw similar trends to $\mathrm{H}-\mathrm{AA}$ but with less dramatic spikes in $\mathrm{pH}$. After $21 \mathrm{~d}$, treatments $\mathrm{H}-\mathrm{HCl}$ and $\mathrm{H}-\mathrm{Ca} / \mathrm{Mg}+\mathrm{Mn}$ remained below a $\mathrm{pH}$ of 6.2 , with one exception, where $\mathrm{H}-\mathrm{HCl}$ leapt to 6.6 at $38 \mathrm{~d}$. Treatment $\mathrm{H}-\mathrm{Ca} / \mathrm{Mg}$ did not stay below a pH of 6.2 until after $24 \mathrm{~d}$. These three treatments occasionally experienced a pH below 5 between 28 and $48 \mathrm{~d}$, requiring $\mathrm{NaOH}$ to raise the $\mathrm{pH}$.

Because of the difference in $\mathrm{pH}$ spikes in the $\mathrm{H}-\mathrm{HCl}, \mathrm{H}-\mathrm{AA}, \mathrm{H}-\mathrm{Ca} / \mathrm{Mg}$, and $\mathrm{H}-$ $\mathrm{Ca} / \mathrm{Mg}+\mathrm{Mn}$ treatments, they received differing amounts of acetic acid and $\mathrm{NaOH}$. Treatment $\mathrm{H}-\mathrm{HCl}$ received, on average, 0.12 moles $\left(300 \mu \mathrm{g} \cdot \mathrm{mL}^{-1}\right)$ of $\mathrm{HCl}$ and $3.0 \mathrm{~g}$ of $\mathrm{NaOH}$. The acetic acid treatments received, on average, $0.61,0.20$, and 0.17 moles $(2.600,860$, and $730 \mu \mathrm{g} \cdot \mathrm{mL}^{-1}$ ) of acetic acid (including the amount given to initially adjust $\mathrm{pH}$ prior to planting) and $0.06,3.1$, and $3.3 \mathrm{~g}$ of $\mathrm{NaOH}$ for the $\mathrm{H}-\mathrm{AA}, \mathrm{H}-\mathrm{Ca} / \mathrm{Mg}$, and $\mathrm{H}-\mathrm{Ca} / \mathrm{Mg}+\mathrm{Mn}$ treatments, respectively, over the course of the study. The moles of acid (protons) that the H-AA treatment received were statistically greater than the other three treatments.

It is also noteworthy that a precipitate was observed in all treatments except the ctrl. No analysis of the precipitate was performed, but Cole et al. [1] also observed a similar precipitate, and they suggest that it was a carbonate.

\section{Discussion}

\subsection{Effectiveness of the SNS Solution for Growing Plants Hydroponically}

One of the primary purposes of this study was to determine the effectiveness of the newly developed SNS solution compared with a traditional, widely used hydroponic solution (Hoagland) developed more than 70 years ago [10]. Although not originally published in peer-reviewed literature, this solution and slight modifications of the original have been used successfully in numerous studies and other endeavors, such as with Arkoun et al. [35], Barben et al. [15-17], Benson et al. [12,23], Buxton et al. [26], Dale et al. [22], Geary et al. [14], Hawrylak-Nowak et al. [46], Hopkins et al. [27,28,30], Hughes et al. [21], Jolley et al. [29], Nichols et al. [19], Pitchay and Mikkelsen [4], and Summerhays et al. [8]. As such, the Hoagland solution is a reasonable standard for comparison with the SNS solution.

The SNS and Hoagland solutions in this study had identical levels of Ca and Mg but differences for all other nutrients (Table 2). The concentrations in the SNS nutrient solution for N, P, K, Fe, B, Mn, and Mo were higher than for the Hoagland solution and were lower for $\mathrm{S}, \mathrm{Zn}, \mathrm{Cu}$, and $\mathrm{Cl}$. Other than $\mathrm{S}$ and $\mathrm{Mn}$, these differences were relatively large (ranging from 1.3 to 42 times difference).

These solutions resulted in variable nutrient concentrations in plant tissue. Other than $\mathrm{B}, \mathrm{Ca}, \mathrm{Mg}, \mathrm{N}, \mathrm{Zn}$, and Mo at the $20 \mathrm{~d}$ harvest and Fe and Mn at the $53 \mathrm{~d}$ harvest, the comparative differences of shoot nutrient concentrations generally coincided with the nutrient solution concentrations for the SNS and Hoagland solutions. By $53 \mathrm{~d}$, all shoot nutrient concentrations were equivalent or significantly different, in the same direction as the nutrient solution ratios. Despite some of the large differences in solutions, the differences in the shoots were generally not significant, other than for $\mathrm{K}$ and $\mathrm{Zn}$ (and likely $\mathrm{N}$ as well, although this was not replicated). Hoagland resulted in 1.3 and 1.4 times more $\mathrm{N}$ and $\mathrm{K}$, respectively, in the shoots at $53 \mathrm{~d}$ than the SNS solution by comparison of treatments ctrl and H. Moreover, the SNS solution had 3.8 times more $\mathrm{Zn}$ than Hoagland by the same comparison. These differences are potentially important and warrant further study.

Despite some nutritional differences, the SNS solution evaluated in this study compares favorably to Hoagland. There were no negative impacts, and some measured growth 
parameters were numerically greater. These findings, along with unpublished preliminary work on this and other species, demonstrate that the SNS solution can be used to grow healthy soybeans hydroponically at least as effectively as the Hoagland solution.

Cole et al. [1] further demonstrated that the SNS solution, with minor variations from what was used in this study, was used effectively to grow quinoa to maturity. As with this soybean study, they suggest that improvements to the solution would possibly improve quinoa growth. However, overall, the SNS solution has proven to be effective at growing both soybean and quinoa.

\subsection{Effectively Creating Individual Nutrient Deficiencies/Toxicities}

A hydroponic solution that is comprised of single-nutrient sources, such as the SNS solution used in this study, provides a significant improvement over Hoagland and other dual-nutrient source solutions. The Hoagland solution and all other hydroponic solutions for which we are aware pair several nutrients as cationic and anionic salts. These dualnutrient sources result in interacting factors when adjusting a single nutrient for the study of various rates of that nutrient. For example, if P nutrition levels were being studied using a modified Hoagland solution, with varying levels added as treatments, the $\mathrm{K}$ levels would vary proportionally if the source for $\mathrm{P}$ were supplied as $\mathrm{KH}_{2} \mathrm{PO}_{4}$. Researchers studying $\mathrm{P}$ and using this source have compensated by adding another $\mathrm{K}$ source-adding it at high concentrations, with the idea of being certain that $\mathrm{K}$ is found in abundance [15-18]. Although this approach has worked for individual nutrient studies, it becomes increasingly problematic if multiple nutrients are studied at the same time, such as with Cole et al. [1].

Often, there is an attempt to overcome the effects of adjusting a dual-source nutrient by either (1) ensuring that the associated ion is present in large abundance so that it is not deficient or (2) adding a secondary source of the associated ion. Steinberg [11] varied Mo concentrations with molybdenum chloride $\left(\mathrm{Cl}_{10} \mathrm{Mo}_{4}\right)$ but maintained $\mathrm{Cl}$ at relatively high concentrations so as not to cause an interacting $\mathrm{Cl}$ deficiency. However, this method of ensuring a large abundance of a nutrient while varying its concentration can have interactive effects on other nutrients. In addition, this approach is not possible if a deficiency of that nutrient is being induced in the same study (e.g., if Steinberg was also studying $\mathrm{Cl}$ in the same study). The alternative option, adding a secondary source of the associated ion, can also cause difficulties. For example, Barben et al. [15,17] created P and Zn deficiencies at various concentrations by adjusting quantities of potassium phosphate and zinc sulfate. Consequently, $\mathrm{K}$ and $\mathrm{S}$ differences were also present in addition to the $\mathrm{P}$ and $\mathrm{Zn}$ differences. This was addressed by adding additional $\mathrm{K}$ and $\mathrm{S}$ to avoid these nutrients being deficient. Nevertheless, the nutrient concentrations for $\mathrm{K}$ and $\mathrm{S}$ still varied between treatments, causing concern for possible nutrient or other physiological interactions. It is unlikely that these differences void the findings in these studies, but it does raise questions and highlight a need for an improved system that allows a single nutrient to be varied [1].

Similarly, Pitchay [3], Gibson [2], and Pitchay and Mikkelsen [4,5] created several nutrient deficiencies using, essentially, a modified Hoagland solution. To create the deficiencies, it appears that Pitchay [3] likely substituted any nutrient as an anion (e.g., sulfate), with $\mathrm{Cl}$ and any nutrient as a cation (e.g., $\mathrm{Mg}$ ) with sodium ( $\mathrm{Na}$ ). With the $\mathrm{Mg}$ and $\mathrm{S}$ sources being magnesium sulfate, magnesium chloride could then be added for reduced S levels, and sodium sulfate could be added for reduced Mg levels. This likely does not negate their findings, but interacting factors could result from the varied $\mathrm{Cl}$ and $\mathrm{Na}$ concentrations [1].

Additionally, Gibson [2] studied N and K impacts on plant growth and rooting of stem cuttings for Scaevola (Scaevola aemula R. Br.), New Guinea impatiens (Impatiens hawkeri W. Bull), and vegetative strawflower (Bracteantha bracteate (Vent.) Anderb \& Haegi; formerly Xeranthemum bracteatum Vent). When $\mathrm{N}$ and $\mathrm{K}$ levels were changed, however, $\mathrm{S}$ levels were also impacted because magnesium sulfate was used with both potassium sulfate and magnesium nitrate. The $\mathrm{S}$ levels in the solution varied throughout the study from 3-215 $\mathrm{mg} \cdot \mathrm{L}^{-1}$. This variation may have resulted in an $\mathrm{S}$ interaction [1]. 
It is also important to recognize that different species, and even varieties/cultivars of species, often have unique optimum concentrations of nutrients. For example, differing optimum nutrient levels of $\mathrm{P}$ and $\mathrm{Zn}$ have been shown for maize [19] (Zea mays L.) than for potato $[15,17]$ (Solanum tuberosum L.). Finding the optimum levels of a single nutrient may also alter the optimum levels of other nutrients, requiring iterations of experiments to optimize all nutrients [15-19]. It would be ideal for each species or variety grown in research or commercial hydroponic systems to be studied to find the optimal hydroponic nutrient concentrations. This is not as practical with existing published nutrient solutions because it is more difficult to adjust a single nutrient within a study without affecting other nutrients when using a dual-nutrient source solution [1].

The SNS solution mostly eliminates mineral nutrient interactions, although it does result in alterations of nonmineral elements (such as hydrogen). For example, if various $P$ rates are used with the SNS solution, there will be simultaneous changes to the moles of hydrogen (protons) being added with $\mathrm{H}_{3} \mathrm{PO}_{4}$. This will influence $\mathrm{pH}$, which requires adjustment with an acid or base, such as $\mathrm{NaOH}$, which would create an imbalance for $\mathrm{Na}$. However, we surmise that it is relatively better to have imbalances of the nonessential $\mathrm{Na}$ ion than have essential nutrient imbalances. Similarly, if $\mathrm{Mg}$ were being studied with the SNS solution, there would be an imbalance of carbonate as this is the source for $\mathrm{Mg}$. However, this will either be neutralized as the carbonate is transformed to carbon dioxide (g) if the solution is acidic, or it will precipitate as an abundance of carbonates in alkaline solutions. This difference in carbonates can be resolved with sodium bicarbonate or sodium carbonate. However, increasing carbonate levels could cause some nutrients to precipitate out of the solution with the carbonates. Nevertheless, as nutrients are taken up during plant growth, the precipitate can then dissolve back into the solution as a function of equilibrium chemistry. This could result in a limit on the maximum concentration available to the plant. This is, therefore, an important consideration when adjusting nutrient concentrations since carbonate levels can also be impacted.

We propose that the SNS solution is better suited for hydroponic studies involving multiple rates of one or more nutrients. This supports evidence shown in Cole et al. [1], where multiple nutrient deficiencies were successfully studied (although further work is underway to refine the SNS solution to achieve deficiencies of all the nutrients attempted in that study that were not substantively deficient).

\subsection{Solution $p H$ Concerns}

Ideally, a hydroponic solution should somewhat mimic soil conditions. This is especially true with regard to $\mathrm{pH}$, which is well buffered in most soils-remaining somewhat constant during a growing season. This is not typically a large concern for commercial hydroponic applications, although $\mathrm{pH}$ changes can affect nutrient availability. However, this is a concern for nutritional and other studies, where it is desirable for the chemistry of the nutrient solution to somewhat match the typical soil environment.

Many hydroponic nutrient studies have reported that $\mathrm{pH}$ has to be regularly adjusted on a daily to weekly basis to maintain a consistent growing environment $[8,26,30,47]$. Most nutrients also show varying solubility and plant availability as a function of solution $\mathrm{pH}$ [9]. Various acids or bases used to adjust $\mathrm{pH}$ may also provide some interacting factors on the plants. For example, Wortman [47] used potassium hydroxide $(\mathrm{KOH}), \mathrm{H}_{3} \mathrm{PO}_{4}$, and acetic acid; Hopkins et al. [30] used $\mathrm{NaOH}$ to maintain the $\mathrm{pH}$ of their studies. While the presence of these acids or bases likely did not greatly affect the results of these studies, they may have had small impacts through the addition of minerals such as $\mathrm{K}, \mathrm{P}$, and/or $\mathrm{Na}$ and the increased concentration of acetates. Many acids and bases are not ideal for use in this new solution because of the presence of additional nutrients. Consequently, acetic acid and $\mathrm{HCl}$ were tested in the study presented herein.

Unfortunately, the variability of solution $\mathrm{pH}$ is a weakness of both Hoagland and SNS solutions, with both solutions having dramatic, albeit opposite, $\mathrm{pH}$ changes over the course of the study reported herein. For the SNS solution, this was in spite of the MES biological 
$\mathrm{pH}$ buffer that was added. The MES is intended for buffering in the acidic range, but its presence in the study did not appear to have a substantial influence on $\mathrm{pH}$. It is possible that the concentration of MES could be increased to evaluate if that would enhance the buffering, but MES can be toxic to some plants. Parfitt et al. [48] found it toxic to tobacco (Nicotiana tabacum L.) at $0.05 \mathrm{M}$, and Kagenishi et al. [49] found that $1 \%(w / v ; \sim 0.05 \mathrm{M})$ MES inhibited root growth in thale cress (Arabidopsis thaliana). This may leave some room for increase, as the MES concentration used in this study was $0.002 \mathrm{M}$ (Table 2).

The other approach that was evaluated with the SNS solution in this study was to manually adjust $\mathrm{pH}$ to a predetermined level by adding acids or bases three times weekly. Unfortunately, this was not fully effective. Neither $\mathrm{HCl}$ nor acetic acid buffered the SNS solution efficiently, with the $\mathrm{pH}$ rebounding back to near where it was prior to adjustment in a short time.

Acetic acid was selected for evaluation because it does not contain any mineral nutrients and, thus, potentially lends itself for use with the SNS solution, where strict control of all mineral nutrients is desired. However, it is apparent from the results of this study that acetic acid is toxic to plants when applied at the concentrations needed for $\mathrm{pH}$ adjustment. The H-AA treatment received high concentrations of acetic acid ( 0.61 moles or $2600 \mu \mathrm{g} \cdot \mathrm{mL}^{-1}$ ) that resulted in negative impacts for several growth parameters. For example, at the $53 \mathrm{~d}$ harvest, the H-AA solution had less than half of the shoot and root biomass of the ctrl, $\mathrm{H}$, and $\mathrm{H}-\mathrm{HCl}$ treatments. The reduced $\mathrm{Ca} / \mathrm{Mg}$ required much less acetic acid for $\mathrm{pH}$ adjustment $\left(0.17-0.20\right.$ or $\left.730-860 \mu \mathrm{g} \cdot \mathrm{mL}^{-1}\right)$ and, as a result, had less dramatic impacts on growth. However, there were still trends for slight negative impacts on growth that eliminates acetic acid from serious consideration for use in the SNS solution.

Others also observed toxicities from acetic acid in hydroponics, though information on this toxicity is somewhat limited. However, the results of this study were generally in alignment with other studies. Fortes et al. [24] and Kopp et al. [50] report the toxicity of acetic acid in varieties of rice (Oryza sativa L.). Toxicity was observed by $2.5 \mathrm{mM}$ $\left(150 \mu \mathrm{g} \cdot \mathrm{mL}^{-1}\right)$ of acetic acid by Fortes et al. [24], although this was not reported as a critical point of toxicity. Vines et al. [51] found that a toxicity in tomatoes (Lycopersicon esculentum Mill cv. Ailsa Craig) occurred with as low as $10 \mu \mathrm{g} \cdot \mathrm{mL}^{-1}$. These reported levels were all lower than the toxicities observed in the present study with soybean. This may be due to differences in species and growing environment. Kopp et al. [50] suggest that for rice, acetic acid toxicity is dependent on genotype, and it is very likely that tolerance is variable by species. In addition, Vines et al. [51] had a much lower $\mathrm{pH}(2.7-4.7)$ when the plants experienced toxicity.

Although not desirable for use with the SNS solution due to the presence of a mineral nutrient $(\mathrm{Cl}), \mathrm{HCl}$ was included in the present study for comparison with acetic acid. This acid did not have significant deleterious impacts on the plants. No statistical difference or negative trends were observed in any growth measures at the 32 or $53 \mathrm{~d}$ harvests with this and the unadjusted Hoagland and SNS solution treatments. This provides evidence that the negative impacts for acetic acid were due to direct toxicity and not because of $\mathrm{pH}$ adjustment.

Thus, $\mathrm{pH}$ adjustment for the SNS solution requires further study. Using $\mathrm{HCl}$ is a possibility for $\mathrm{pH}$ adjustments, but doing so will result in the addition of $\mathrm{Cl}$ ions to the solution, which precludes its use if attempting to study this micronutrient. Furthermore, $\mathrm{Cl}$ toxicity is a possibility, although that was not observed in this study, despite a much higher $\mathrm{Cl}$ concentration in the SNS solution than in the Hoagland solution. Other nonmineral nutrients containing acids (carbonic, formic, citric, acetylsalicylic, etc.) could be used for $\mathrm{pH}$ adjustment, but their potential toxicity and interactions with the nutrient solutions would need careful consideration and study. Additionally, their impact on excessive microbial growth in the nutrient solution would need evaluation, which we have found to be problematic for citric acid (unpublished data). It is also possible that MES concentration could be increased to reduce the $\mathrm{pH}$ spikes, although MES toxicity is a concern [48,49]. 
Other biological $\mathrm{pH}$ buffers are also possible solutions, especially if desiring to buffer the $\mathrm{pH}$ at levels where MES is known to be ineffective.

Overall, it would be ideal to have a solution where $\mathrm{pH}$ could be maintained easily within a small $\mathrm{pH}$ range without the addition of mineral nutrients. The SNS solution initially resisted any $\mathrm{pH}$ movement into the acidic range (possibly due to buffering of the carbonate precipitates in the basic range), causing significant fluctuations in $\mathrm{pH}$ as the study progressed. The mineral-free acid used (acetic acid) proved to induce toxicity. The SNS solution ought to be in the slightly acidic range, where plant growth and nutrient availability are optimized. However, some studies may be desired to have either a more acidic or a more alkaline condition, depending on the study objectives. It is desirable to find alternatives for any $\mathrm{pH}$ scenario but, regardless, the $\mathrm{pH}$ should be somewhat constant to reflect soil conditions.

\subsection{Potential Nutrient Concentration Adjustments for Future Studies}

The results of this study show that the SNS solution is effective in growing plants, with nutrients derived from single mineral nutrient sources easily adjusted without interfering with other nutrients. However, it is desirable to grow plants that are more in line with field observations of "typical" soybean nutrient concentrations. The data reveal several adjustments that are needed to help achieve this goal.

Possibly the most critical adjustment is for $\mathrm{Cu}$. The concentrations for $\mathrm{Cu}$ in this study, at both the early and late harvests, are 2-4 times lower than what Bryson et al. [40] listed as typical for soybean at similar growth stages (Table 7). Cole et al. [1] found similar results with quinoa grown with a very similar nutrient solution as in this study, but with lower $\mathrm{Ca}$, $\mathrm{Mg}$, and Fe concentrations and a higher $\mathrm{Mn}$ and $\mathrm{B}$ concentration. Unlike soybean, there is not a large nutrient concentration database for quinoa to use for comparison. Rather, Cole et al. [1] compared the nutrient concentrations of quinoa with its close relative, sugar beet (Beta vulgaris L.). Similar to this study, Cole et al. [1] found that $\mathrm{Cu}$ concentrations were lower than what would be expected for sugar beet by day 56 , with about the same magnitude as in this study.

However, it is noteworthy that the shoot $\mathrm{Cu}$ concentrations for soybean grown in this study with the historically successful Hoagland solution were at a similar level as the SNS-solution-grown plants (Table 7). It is possible that the shoot $\mathrm{Cu}$ values measured are above the critical value. Bryson et al. (2014) did not state the critical levels but, rather, listed commonly observed plant tissue measures from field observations and studies.

Several studies have shed some light on possible critical levels of $\mathrm{Cu}$. Adams et al. [52,53] suggest a critical level of $1.5 \mathrm{mg} \cdot \mathrm{kg}^{-1}$ for soybean, but Fageria [54] stated that the critical level, based on greenhouse experiments harvested three weeks after sowing, is $7 \mathrm{mg} \cdot \mathrm{kg}^{-1}$ for soybean. They found this to be similar for common bean (Phaseolus vulgaris L.) and maize, but about half the values for wheat (Triticum aestivum L.) and rice. Heitholt et al. [55] also suggest that a higher critical level is appropriate. They found that 7.7 and $5.2 \mathrm{mg} \cdot \mathrm{kg}^{-1}$ were deficient for leaf $\mathrm{Cu}$ concentrations at the R3 and R6 growth stages, respectively (compared to fertilized plants, with $8.9-9.2$ and $5.4-6.3 \mathrm{mg} \cdot \mathrm{kg}^{-1}$ at the same stages). The unfertilized control in these greenhouse studies had reduced fruit and total biomass yields, although there were no differences in leaf, stalk, or root biomass. Santos et al. [56] found similar results in a greenhouse trial. The unfertilized control resulted in $\mathrm{Cu}$ deficiency (yield, as well as shoot, root, and several other measured parameters, were impacted by $\mathrm{Cu}$ deficiency) in two soils evaluated regardless of the limestone rate. The leaf $\mathrm{Cu}$ concentrations were $1.3-2.1 \mathrm{mg} \cdot \mathrm{kg}^{-1}$ for the control, compared to $3.2-7.4 \mathrm{mg} \cdot \mathrm{kg}^{-1}$ for the fertilized treatment resulting in the highest yield. It is also noteworthy that some evidence of toxicity was observed at the highest $\mathrm{Cu}$ fertilizer rates, with leaf $\mathrm{Cu}$ concentrations higher than $\sim 10 \mathrm{mg} \cdot \mathrm{kg}^{-1}$. Moreira and Moraes [57] found similar results with a yield response to $\mathrm{Cu}$ fertilizer in two soils, where the unfertilized control had $\mathrm{R} 2$ leaf $\mathrm{Cu}$ of 2.5 and $3.4 \mathrm{mg} \cdot \mathrm{kg}^{-1}$ compared to 4.3 and $4.5 \mathrm{mg} \cdot \mathrm{kg}^{-1}$ in the treatment with the highest yield. In their study, there was also strong evidence of $\mathrm{Cu}$ toxicity, but this was not reflected in 
increased leaf $\mathrm{Cu}$ concentrations, higher than the optimum. In a field study with soybean, Moreira et al. [58] also showed significant yield and other responses to $\mathrm{Cu}$ fertilization. In contrast with the greenhouse studies above, the control in their study was $\mathrm{Cu}$ deficient even though the leaf $\mathrm{Cu}$ concentration at the $\mathrm{R} 2$ growth stage averaged $6.3 \mathrm{mg} \cdot \mathrm{kg}^{-1}$, with the fertilized plots significantly higher at $7.1-7.9 \mathrm{mg} \cdot \mathrm{kg}^{-1}$. Once again, toxicity was reached at the highest rates with leaf $\mathrm{Cu}$ at $8.6 \mathrm{mg} \cdot \mathrm{kg}^{-1}$. Moreira et al. [58] pointed out that these results are in contrast to Urano et al. [59], who suggested a critical level of 2.6 to $17.2 \mathrm{mg} \cdot \mathrm{kg}^{-1}$. Lastly, Manchanda et al. [60] reported shoot concentrations of 6.9 $\mathrm{mg} \cdot \mathrm{kg}^{-1}$ for unfertilized soybean and $8.2 \mathrm{mg} \cdot \mathrm{kg}^{-1}$ for fertilized soybean, harvested $60 \mathrm{~d}$ after sowing.

Based on the above studies, it is likely that at the early growth stages, the critical level for $\mathrm{Cu}$ is at or above $7 \mathrm{mg} \cdot \mathrm{kg}^{-1}$, while it is closer to 5 or $6 \mathrm{mg} \cdot \mathrm{kg}^{-1}$ at later growth stages. Soybeans grown in this study had concentrations from $2.1-4.0 \mathrm{mg} \cdot \mathrm{kg}^{-1}$ at the $20 \mathrm{~d}$ harvest and $1.5-3.1 \mathrm{mg} \cdot \mathrm{kg}^{-1}$ at the $53 \mathrm{~d}$ harvest (Table 7), which is likely deficient even though no visible deficiencies were observed or measured. Although further research could be done to establish the critical level for soybean grown in hydroponics, the evidence presented above strongly suggests that $\mathrm{Cu}$ levels for the SNS and Hoagland solutions in this study were deficient. The $\mathrm{Cu}$ for the SNS solution needs to be increased by increasing the $\mathrm{Cu}$ in the solution and/or with chelate adjustments.

In addition to $\mathrm{Cu}$, other nutrients that were potentially deficient in the SNS solution were $\mathrm{N}$ and $\mathrm{K}$ (Table 6). The findings of this study are similar to those of Cole et al. [1], which showed that quinoa grown with the SNS solution had lower than desirable shoot $\mathrm{N}$. Although the $\mathrm{N}$ concentration was about $20 \%$ higher than the upper reported "typical" range for the $20 \mathrm{~d}$ harvest in this study, by $53 \mathrm{~d}$, the $\mathrm{N}$ concentration was about $10 \%$ lower than the reported range (Table 6). This would suggest that the $\mathrm{N}$ could be reduced initially, but the total amount applied by the end of the study should be higher-possibly using the concentration found in the Hoagland solution as a guide. Although a much lower magnitude of difference than $\mathrm{Cu}$, adjusting the $\mathrm{N}$ could have a very large difference because $\mathrm{N}$ tends to have relatively greater impacts on growth than all other mineral nutrients [9]. Although soybean is a legume, there was only minimal nodulation formation on roots, and, thus, most of the $\mathrm{N}$ supplied to the plant comes from the nutrient solution. It is also noteworthy that the Hoagland solution tended to stay closer to "typical" at both 20 and $53 \mathrm{~d}$ harvests (Table 6). This is not surprising for the $53 \mathrm{~d}$ harvest but is somewhat unexpected for the $20 \mathrm{~d}$ harvest as the Hoagland solution had $36 \%$ higher N. It is significant that the $\mathrm{N}$ supplied in the Hoagland solution is all in the nitrate- $\mathrm{N}$ form, which possibly explains this differing pattern compared to the SNS solution, which has its $\mathrm{N}$ introduced as an even split between ammonium-N and nitrate-N.

One possible adjustment for the SNS solution would be to increase the proportion of nitrate-N supplied to the plants by having part or the entire amount of $\mathrm{N}$ supplied with nitric acid. However, it has been shown that the ratio of ammonium ions to nitrate ions as an $\mathrm{N}$ source can influence plant growth [13]. It is also noteworthy that altering the ratio of the form of $\mathrm{N}$ supplied would also likely influence the solution's $\mathrm{pH}$ relationships.

The K concentrations were seemingly adequate at the $20 \mathrm{~d}$ harvest but, as with $\mathrm{N}$, were low by $53 \mathrm{~d}$ for the SNS solution (Table 6). These $\mathrm{K}$ concentrations were $10-20 \%$ lower than the "typical" range at the final harvest. This would suggest that the initial rate was adequate but that a higher amount of total $\mathrm{K}$ needs to be added by the end of the study. The Hoagland solution had 50\% more $\mathrm{K}$ and maintained levels more akin to what is observed under field conditions. In slight contrast, quinoa grown with a modified SNS solution (identical $\mathrm{K}$ concentrations) had a shoot $\mathrm{K}$ concentration that was seemingly adequate at $56 \mathrm{~d}$ [1]. However, the quinoa $\mathrm{K}$ concentrations were not so high that an upward adjustment in the nutrient concentration would likely be detrimental. Increasing the $\mathrm{K}$ in the SNS solution by $50 \%$ may result in shoot $\mathrm{K}$ values more closely aligned with field observations and provide enhanced soybean growth. 
In contrast to $\mathrm{Cu}, \mathrm{N}$, and $\mathrm{K}$, some other nutrients were slightly-to-extremely high (Tables 6 and 7). The greatest concern was with $P$, which was 2 to 4 times higher than typically observed field values early in the season (Table 6). The P concentration was high at $20 \mathrm{~d}$ but more typical by $53 \mathrm{~d}$. This is a large concern due to the known antagonism with $\mathrm{P}$ and several of the micronutrients, including $\mathrm{Zn}, \mathrm{Fe}, \mathrm{Mn}$, and $\mathrm{Cu}[9,15-18,38]$. This could have been part of the issue, with Cu potentially being deficient. This data suggests that, potentially, the initial $P$ rates need to be reduced but with the same total amount added through the season. It is noteworthy that the traditionally successful Hoagland solution has 33\% more total $\mathrm{P}$ added and that it showed a similar pattern, with numerically higher concentrations. For comparison, the P concentrations for quinoa were not exorbitantly high at the first harvest and were possibly low (based on a comparison with sugar beet) by the last harvest [1]. This suggests that the optimal approach for P nutrition is different for quinoa compared to soybean. This is similar to differing optimal P concentrations for potato [15-18] and maize [19]. Again, the SNS solution is relatively well suited to developing customized hydroponic nutritional recipes for each unique species, with $\mathrm{P}$ especially important for adjustment.

Other nutrients ( $\mathrm{Ca}, \mathrm{Zn}$, and $\mathrm{B}$ ) were also high by $53 \mathrm{~d}$, although only slightly above the typical observed field value range and not likely a problem (Tables 6 and 7). These nutrients could be considered for reduction, with minimal chance of a negative impact. However, $\mathrm{Zn}$ concentration was hugging the bottom end of the typical observed field value range at $20 \mathrm{~d}$ and reducing the total amount may push it to a deficient status. In addition, although both solutions initially contained identical amounts of total Ca added (Table 2), the Hoagland solution had a significantly higher concentration in the tissue at $20 \mathrm{~d}$ (Table 6), likely due to less or no precipitation of $\mathrm{CaCO}_{3}$ in the Hoagland solution. This difference disappeared by $53 \mathrm{~d}$. It is also noteworthy that treatment ctrl and treatment $\mathrm{H}$ had similar concentrations in the plant tissues for B at both harvests (Table 7) despite solution $\mathrm{H}$ having about double the concentration in the nutrient solution (Table 2). Moreover, plant tissue concentrations were similar for both solutions for $\mathrm{Zn}$ at the early harvest, but there was a massive difference at $53 \mathrm{~d}$, with Hoagland very possibly having a Zn deficiency (Table 7). This is likely due to the drastic difference in $\mathrm{Zn}$ concentration in the nutrient solution, with over five times more $\mathrm{Zn}$ in the SNS solution than Hoagland (Table 2). The other nutrients $(\mathrm{S}, \mathrm{Mg}, \mathrm{Fe}, \mathrm{Mn}$, and $\mathrm{Mo}$ ) that were measured, for which there are published comparative values, had concentrations that fit within the range of what is observed in the field (Tables 6 and 7).

Furthermore, Cole et al. [1] suggested that $B$ and Mn concentrations may be excessive, and this was verified in this study. The B and Mn concentrations used for growing soybean were $80 \%$ of those used by Cole et al. [1] in growing quinoa, with treatment $\mathrm{H}-\mathrm{Ca} / \mathrm{Mg}+\mathrm{Mn}$ having the same Mn concentration as the quinoa. With the decrease in B concentration in the solution, the plant tissue still had slightly high B levels by $53 \mathrm{~d}$. In addition, treatment $\mathrm{H}-\mathrm{Ca} / \mathrm{Mg}+\mathrm{Mn}$ had an excessive $\mathrm{Mn}$ concentration at $53 \mathrm{~d}$. For treatment $\mathrm{H}$, both $\mathrm{B}$ and $\mathrm{Mn}$ were on the upper end of "typical" for soybean and would not likely become deficient if the solution was, again, adjusted downward for both nutrients. Generally, the other nutrients were within an acceptable range, though there is some uncertainty for all nutrients because of a lack of data on healthy quinoa concentrations.

Likely as a consequence of the SNS solution's nutrient sources being paired with carbonates, Cole et al. [1] did find that a precipitate (predominately carbonate) formed in their nutrient solution. This was also observed during this study. In this trial, at the $20 \mathrm{~d}$ harvest, the ctrl had very high $\mathrm{Ca}$, as compared to what is typically measured in field-grown soybean (Bryson et al., 2014; Table 6). All of the SNS solution treatments were significantly lower and in a typically observed field value range. By the $53 \mathrm{~d}$ harvest, there was no statistical difference between any treatments, though all treatments but H-AA had relatively high concentrations. Treatment $\mathrm{H}-\mathrm{Ca} / \mathrm{Mg}+\mathrm{Mn}$, despite having lower $\mathrm{Ca}$ concentrations in the solution than most other treatments, had the highest numerical $\mathrm{Ca}$ concentration. These results suggest that if the precipitate is Ca-based, a Ca precipitate 
may not substantially affect or harm the plants. It also may create a relatively constant equilibrium concentration, as the solution would remain saturated with $\mathrm{Ca}$ ions, with additional ions dissolving from the precipitate as roots take up Ca ions from the solution.

An alternate form of $\mathrm{Ca}$ could be studied to avoid the formation of a precipitate. This was the intention of Treatment $7, \mathrm{H}-\mathrm{Ca}\left(\mathrm{C}_{2} \mathrm{H}_{3} \mathrm{O}_{2}\right)_{2}$. Unfortunately, this treatment had to be discontinued due to poor performance, a pungent odor from the solution, and substantial fungal or bacterial growth that was not present when $\mathrm{CaCO}_{3}$ was the Ca source. It is possible that the acetate ions promoted the fungal growth that occurred. This same fungal growth was not observed (at least not to the same extent) in the treatments that had large amounts of acetate ions provided by acetic acid. The $\mathrm{H}-\mathrm{Ca}\left(\mathrm{C}_{2} \mathrm{H}_{3} \mathrm{O}_{2}\right)_{2}$ treatment initially had 0.14 moles of acetate when the study began and required large quantities of acetic acid as the study progressed. Interestingly, this initial amount of acetate is less than one-quarter of the amount ( 0.61 moles) with which $\mathrm{H}-\mathrm{AA}$ ended the study, possibly suggesting that acetate added in smaller amounts over time may not influence algae growth the same as large quantities at a single instance. It is unclear what the cause of fungal or bacterial growth was during the study, but its presence in all three replicates of $\mathrm{H}-\mathrm{Ca}\left(\mathrm{C}_{2} \mathrm{H}_{3} \mathrm{O}_{2}\right)_{2}$ indicates that acetate may have some benefit to bacteria or fungus present in a system and that $\mathrm{Ca}\left(\mathrm{C}_{2} \mathrm{H}_{3} \mathrm{O}_{2}\right)_{2}$ may not be an ideal calcium source for hydroponics.

A further purpose in conducting this study was to find more ideal concentrations for $\mathrm{Ca}, \mathrm{Mg}$, and $\mathrm{Mn}$ in the nutrient solution. Unfortunately, results are somewhat convoluted due to the possibility of acetic acid toxicity. The Ca concentrations in the shoots at the $53 \mathrm{~d}$ harvest were high, but this was true for all treatments but H-AA (Table 6). It is, therefore, likely that solution concentrations should be reduced in the future. This will likely reduce them more than the concentrations in treatments $\mathrm{H}-\mathrm{Ca} / \mathrm{Mg}$ and $\mathrm{H}-\mathrm{Ca} / \mathrm{Mg}+\mathrm{Mn}$. The $\mathrm{Mg}$ concentrations in shoots were appropriate at both the 20 and $53 \mathrm{~d}$ harvests, so no adjustments are likely necessary. By the $53 \mathrm{~d}$ harvest, Mn concentrations were very high in the $\mathrm{H}-\mathrm{Ca} / \mathrm{Mg}+\mathrm{Mn}$ treatment and approaching high levels in the $\mathrm{H}, \mathrm{H}-\mathrm{AA}$, and $\mathrm{H}-\mathrm{Ca} / \mathrm{Mg}$ treatments; these could reasonably be further reduced in the future (Table 7).

\section{Conclusions}

The results of this study suggest that the Hopkins single-nutrient source (SNS) solution effectively enables plant growth as efficiently as the traditional Hoagland solution. However, the SNS solution has the added benefit that any of the nutrients can be adjusted in concentration without interacting with the concentrations of other nutrients. Despite this success, neither solution had a stable $\mathrm{pH}$, even with frequent adjustment. These $\mathrm{pH}$ spikes are not representative of what happens in soil. Adjusting solution $\mathrm{pH}$ with hydrochloric acid $(\mathrm{HCl})$ was relatively better than using acetic acid in terms of plant growth. Unfortunately, using $\mathrm{HCl}$ precludes any work on $\mathrm{Cl}$ nutrition. Further work is needed for this new hydroponic solution to better buffer the solution $\mathrm{pH}$ and to have plant nutrient concentrations that are more similar to what is measured under field conditions.

Author Contributions: Author contributions in this study include methodology, data curation, visualization, supervision, and writing —original draft preparation, D.L.C. and B.G.H.; conceptualization, validation, project administration, and funding acquisition, B.G.H.; formal analysis, R.L.B. and D.L.C.; investigation, D.L.C., S.J.K., S.R.F., S.H.S., D.K.A.B. and B.G.H.; resources, B.G.H. and R.L.B.; writing-review and editing, S.J.K., S.R.F., S.H.S., D.K.A.B. and R.L.B. All authors have read and agreed to the published version of the manuscript.

Funding: This work was funded internally by Brigham Young University (BYU).

Data Availability Statement: The data presented in this study, as well as statistical analysis outputs, are openly available in a GitHub repository. Data can be found here: https://github.com/dcole9 /Hydroponic_Soybean_Data (accessed on 10 March 2021).

Acknowledgments: This work was supported by the International Plant Nutrition Institute (IPNI) and Brigham Young University (BYU). We thank Robert L. Mikkelsen for assistance and encouragement in this endeavor. We also thank Jeff Hansen for his valuable help with the environmental 
growth chamber. We thank the many students of the BYU Biophysical Soil Chemistry Research Laboratory and the Brigham Young University-Environmental Analytical Laboratory for their efforts in conducting this work.

Conflicts of Interest: The authors acknowledge that there was no conflict of interest in performing this study or analyzing its results.

\section{References}

1. Cole, D.L.; Woolley, R.K.; Buck, R.L.; Tyler, A.; Hopkins, B.G. Mineral Nutrient Deficiencies in Quinoa Grown in Hydroponics with Single Nutrient Salt/Acid/Chelate Sources. J. Plant Nutr. 2020, 43, 1661-1673. [CrossRef]

2. Gibson, J.L. Influence of Mineral Nutrition on Stock Plant Yield and Subsequent Rooting of Stem Cuttings of Scaevola, New Guinea Impatiens, and Vegetative Strawflower. Ph.D. Dissertation, North Carolina State University, Raleigh, NC, USA, 2003.

3. Pitchay, D.S. Impact of 11 Elemental Nutrient Deficiencies on Shoot and Root Growth, and Foliar Analysis of Standards of 13 Ornamental Taxa with Emphasis on Ca and B Control of Root Apical Meristem Development. Ph.D. Dissertation, North Carolina State University, Raleigh, NC, USA, 2003.

4. Pitchay, D.S.; Mikkelsen, R.L. Plant Nutrition Diagnostics: Broccoli; International Plant Nutrition Institute (IPNI): Peachtree Corners, GA, USA, 2016.

5. Pitchay, D.S.; Mikkelsen, R.L. Plant Nutrition Diagnostics: Potato; International Plant Nutrition Institute (IPNI): Peachtree Corners, GA, USA, 2018.

6. Trejo-Téllez, L.I.; Gómez-Merino, F.C. Nutrient Solutions for Hydroponic Systems. In Hydroponics: A Standard Methodology for Plant Biological Researches; Asao, T., Ed.; Intech Open: Rijeka, Croatia, 2012; pp. 1-22. [CrossRef]

7. Summerhays, J.S.; Hopkins, B.G.; Jolley, V.D.; Hill, M.W.; Ransom, C.J.; Brown, T.R. Enhanced Phosphorous Fertilizer (Carbond $\left.\mathrm{P}^{\circledR}\right)$ Supplied to Maize in Moderate and High Organic Matter Soils. J. Plant Nutr. 2015, 38, 1359-1371. [CrossRef]

8. Summerhays, J.S.; Jolley, V.D.; Hill, M.W.; Hopkins, B.G. Enhanced Phosphorous Fertilizers (Carbond P®and AVAIL®) Supplied to Maize in Hydroponics. J. Plant Nutr. 2017, 40, 2889-2897. [CrossRef]

9. Hopkins, B.G. Developments in the Use of Fertilizers. In Achieving Sustainable Crop Nutrition; Rengel, Z., Ed.; Burleigh Dodds Science Publishing: Cambridge, UK, 2020; ISBN 978-1-78676-312-9.

10. Hoagland, D.R.; Arnon, D.I. The Water-Culture Method for Growing Plants Without Soil; California Agriculture Experiment Station Circular 347-2; University of California College of Agriculture: Berkeley, CA, USA, 1950.

11. Steinberg, R.A. Symptoms of Molybdenum Deficiency in Tobacco. Plant Physiol. 1953, 28, 319-322. [CrossRef] [PubMed]

12. Benson, J.H.; Geary, B.; Miller, J.S.; Hopkins, B.G.; Jolley, V.D.; Stevens, M.R. Phytophthora erythroseptica (Pink Rot) Development in Russet Norkotah Potato Grown in Buffered Hydroponic Solutions II. pH Effects. Am. J. Potato Res. 2009, 86, 472-475. [CrossRef]

13. Cao, H.; Ge, Y.; Liu, D.; Cao, Q.; Chang, S.X.; Chang, J.; Song, X.; Lin, X. Nitrate/Ammonium Ratios Affect Ryegrass Growth and Nitrogen Accumulation in a Hydroponic System. J. Plant Nutr. 2010, 34, 206-216. [CrossRef]

14. Geary, B.; Clark, J.; Hopkins, B.G.; Jolley, V.D. Deficient, Adequate and Excess Nitrogen Levels Established in Hydroponics for Biotic and Abiotic Stress-Interaction Studies in Potato. J. Plant Nurt. 2015, 38, 41-50. [CrossRef]

15. Barben, S.A.; Hopkins, B.G.; Jolley, V.D.; Webb, B.L.; Nichols, B.A. Optimizing Phosphorous and Zinc Concentrations in Hydroponic Chelator-Buffered Nutrient Solution for Russet Burbank Potato. J. Plant Nutr. 2010, 33, 557-570. [CrossRef]

16. Barben, S.A.; Hopkins, B.G.; Jolley, V.D.; Webb, B.L.; Nichols, B.A. Phosphorous and Manganese Interactions and Their Relationships with Zinc in Chelator-Buffered Solution Grown Russet Burbank Potato. J. Plant Nutr. 2010, 33, 752-769. [CrossRef]

17. Barben, S.A.; Hopkins, B.G.; Jolley, V.D.; Webb, B.L.; Nichols, B.A. Phosphorous and Zinc Interactions in Chelator-Buffered Solution Grown Russet Burbank Potato. J. Plant Nutr. 2010, 33, 587-601. [CrossRef]

18. Barben, S.A.; Hopkins, B.G.; Jolley, V.D.; Webb, B.L.; Nichols, B.A.; Buxton, E.A. Zinc, Manganese and Phosphorous Interrelationships and Their Effects on Iron and Copper in Chelator-Buffered Solution Grown Russet Burbank Potato. J. Plant Nutr. 2011, 34, 1144-1163. [CrossRef]

19. Nichols, B.A.; Hopkins, B.G.; Jolley, V.D.; Webb, B.L.; Greenwood, B.G.; Buck, J.R. Phosphorus and Zinc Interactions and Their Relationships with Other Nutrients in Maize Grown in Chelator-Buffered Nutrient Solution. J. Plant Nutr. 2012, 35, $123-141$. [CrossRef]

20. Ochigbo, A.E.; Bello, L.L. Screening of Soybean Varieties for Phosphorus Use Efficiency in Nutrient Solution. Agric. Biol. J. N. Am. 2014, 5, 68-77.

21. Hughes, D.F.; Jolley, V.D.; Brown, J.C. Roles for Potassium in the Iron-Stress Response Mechanisms of Strategy I and Strategy II Plants. J. Plant Nutr. 1992, 15, 1821-1839. [CrossRef]

22. Dale, M.E.; Paparozzi, E.T.; Carr, J.D. Sulfur Deficinecy in Poinsettia. HortScience 1990, 25, 424-426. [CrossRef]

23. Benson, J.H.; Geary, B.; Miller, J.S.; Jolley, V.D.; Hopkins, B.G.; Stevens, M.R. Phytophthora erythroseptica (Pink Rot) Development in Russet Norkotah Potato Grown in Buffered Hydroponic Solutions I. Calcium Nutrition Effects. Am. J. Potato Res. 2009, 86, 466-471. [CrossRef]

24. Fortes, M.d.Á.; de Sousa, R.O.; Schmidt, F.; de Oliveira, A.C.; Vahl, L.C. Calcium Effects on Acetic Acid Toxicity in Rice. Commun. Soil Sci. Plant Anal. 2009, 40, 2536-2544. [CrossRef]

25. Hermans, C.; Verbruggen, N. Physiological Characterization of Mg Deficiency in Arabidopsis thaliana. J. Exp. Bot. 2005, 56, 2153-2161. [CrossRef] [PubMed] 
26. Buxton, E.A.; Hopkins, B.G.; Jolley, V.D.; Webb, B.L.; Christensen, R.C. Iron Efficiency in Kentucky Bluegrass not Related to Phytosiderophore Release. J. Plant Nutr. 2012, 35, 311-329. [CrossRef]

27. Hopkins, B.G.; Jolley, V.D.; Brown, J.C. Differential Response of Fe-Inefficient Muskmelon, Tomato, and Soybean to Phytosiderophore Released by Coker 227 Oat. J. Plant Nutr. 1992, 15, 35-48. [CrossRef]

28. Hopkins, B.G.; Jolley, V.D.; Brown, J.C. Variable Inhibition of Iron Uptake by Oat Phytosiderophore in Five Soybean Cultivars. J. Plant Nutr. 1992, 15, 125-135. [CrossRef]

29. Jolley, V.D.; Cook, K.A.; Hansen, N.C.; Stevens, W.B. Plant Physiological Responses for Genotypic Evaluation of Iron Efficiency in Strategy I and Strategy II Plants-A Review. J. Plant Nutr. 1996, 19, 1241-1255. [CrossRef]

30. Hopkins, B.G.; Whitney, D.A.; Lamond, R.E.; Jolley, V.D. Phytosiderophore Release by Sorghum, Wheat, and Corn Under Zinc Deficiency. J. Plant Nutr. 1998, 21, 2623-2637. [CrossRef]

31. Hebbern, C.A.; Laursen, K.H.; Ladegaard, A.H.; Schmidt, S.B.; Pedas, P.; Bruhn, D.; Schjoerring, J.K.; Wulfsohn, D.; Husted, S. Latent Manganese Deficiency Increases Transpiration in Barley (Hordeum vulgare). Physiol. Plant 2009, 135, 307-316. [CrossRef] [PubMed]

32. Gorgé, J.L.; Lastra, O.; Chueca, A.; Lachica, M. Use of Photosynthetic Parameters for the Diagnosis of Copper Deficiency in Pinus radiata Seedlings. Physiol. Plant 1985, 65, 508-512. [CrossRef]

33. Yu, X.; Bell, P.F. Nutrient Deficiency Symptoms and Boron Uptake Mechanisms of Rice. J. Plant Nutr. 1998, 21, $2077-2088$. [CrossRef]

34. Bowen, J.E. Essentiality of Chlorine for Optimum Growth of Sugarcane. In Proceedings of the 14th Congress, International Society of Sugar Cane Technology, Baton Rouge, LA, USA, 22 October-5 November 1971; International Society of Sugar Cane Technologists: Réduit, Mauritius, 1971; pp. 1102-1112.

35. Arkoun, M.; Jannin, L.; Laîné, P.; Etienne, P.; Masclaux-Daubresse, C.; Citerne, S.; Garnica, M.; Garcia-Mina, J.-M.; Yvin, J.-C.; Ourry, A. A Physiological and Molecular Study of the Effects of Nickel Deficiency and Phenylphosphorodiamidate (PPD) Application on Urea Metabolism in Oilseed Rape (Brassica napus L.). Plant Soil 2013, 362, 79-92. [CrossRef]

36. Thys, C.; Vanthomme, P.; Schrevens, E.; De Proft, M. Interactions of Cd with Zn, Cu, Mn, and Fe for Lettuce (Lactuca sativa L.) in Hydroponic Culture. Plant Cell Environ. 1991, 14, 713-717. [CrossRef]

37. Hopkins, B.G.; (Brigham Young University, Provo, UT, USA). Personal Communication, 2020.

38. Hopkins, B.G.; Hansen, N.C. Phosphorus Management in High Yield Systems. J. Environ. Qual. 2019, 48, 1265-1280. [CrossRef] [PubMed]

39. Bennett, W.F. Nutrient Deficiencies and Toxicities in Crop Plants; Bennett, W.F., Ed.; APS Press: St. Paul, MN, USA, 1993.

40. Bryson, G.M.; Mills, H.A.; Sasseville, D.N.; Jones, J.B.; Barker, A.V. Plant Analysis Handbook IV; Bryson, G.M., Mills, H.A., Eds.; MicroMacro Publishing: Athens, GA, USA, 2014.

41. Bender, R.R.; Haegele, J.W.; Below, F.E. Nutrient Uptake, Partitioning, and Remobilization in Modern Soybean Varieties. Agronomy 2015, 107, 563-573. [CrossRef]

42. Hoeft, R.G.; Nafziger, E.D.; Johnson, R.R.; Aldrich, S.R. Modern Corn and Soybean Production; MCSP Publications: Savoy, IL, USA, 2000.

43. Miransari, M. Soybeans, Stress, and Nutrients. In Environmental Stresses in Soybean Production: Soybean Production; Miransari, M., Ed.; Volume 2; Academic Press: Cambridge, MA, USA, 2016; pp. 273-298, ISBN 9780128015353.

44. R Core Team. R: A Language and Environment for Statistical Computing; R Foundation for Statistical Computing: Vienna, Austria, 2019. Available online: https:/ / www.R-project.org/ (accessed on 31 January 2020).

45. R Documentation, Adjust P-Values for Multiple Comparisons. 2019. Available online: http://stat.ethz.ch/R-manual/R-devel/ library/stats/html/p.adjust.html (accessed on 25 November 2019).

46. Hawrylak-Nowak, B.; Dresler, S.; Matraszek, R. Exogenous Malic and Acetic Acids Reduce Cadmium Phytotoxicity and Enhance Cadmium Accumulation in Roots of Sunflower. Plant Physiol. Biochem. 2015, 94, 225-234. [CrossRef] [PubMed]

47. Wortman, S.E. Crop Physiological Response to Nutrient Solution Electrical Conductivity and pH in an Ebb-and-Flow Hydroponic System. Sci. Hortic. 2015, 194, 34-42. [CrossRef]

48. Parfitt, D.E.; Almehdi, A.A.; Bloksberg, L.N. Use of Organic Buffers in Plant Tissue-Culture Systems. Sci. Hortic. 1988, 36, 157-163. [CrossRef]

49. Kagenishi, T.; Yokawa, K.; Baluška, F. MES Buffer Affects Arabidopsis Root Apex Zonation and Root Growth by Suppressing Superoxide Generation in Root Apex. Front. Plant Sci. 2016, 7, 79. [CrossRef] [PubMed]

50. Kopp, M.M.; da Luz, V.K.; de Sousa, R.O.; da Maia, L.C.; Sobrinho, F.d.S.; de Aliveira, A.C. Organic Acid Effects on Nutrient Uptake by Rice. Commun. Soil Sci. Plant Anal. 2012, 43, 2512-2520. [CrossRef]

51. Vines, J.R.L.; Jenkins, P.D.; Foyer, C.H.; French, M.S.; Scott, I.M. Physiological Effects of Peracetic Acid on Hydroponic Tomato Plants. Ann. Appl. Biol. 2003, 143, 153-159. [CrossRef]

52. Adams, M.L.; Norvell, W.A.; Philpot, W.D.; Peverly, J.H. Spectral Detection of Micronutrient Deficiency in 'Bragg' Soybean. Agron. J. 2000, 92, 261-268. [CrossRef]

53. Adams, M.L.; Norvell, W.A.; Philpot, W.D.; Peverly, J.H. Toward the Discrimination of Manganese, Zinc, Copper, and Iron Deficiency in 'Bragg' Soybean Using Spectral Detection Methods. Agron. J. 2000, 92, 268-274. [CrossRef]

54. Fageria, N.K. Adequate and Toxic Levels of Copper and Manganese in Upland Rice, Common Bean, Corn, Soybean, and Wheat Grown on an Oxisol. Commun. Soil Sci. Plant Anal. 2001, 32, 1659-1676. [CrossRef] 
55. Heitholt, J.J.; Sloan, J.J.; MacKown, C.T. Copper, Manganese, and Zinc Fertilization Effects on Growth of Soybean on a Calcareous Soil. J. Plant Nutr. 2002, 25, 1727-1740. [CrossRef]

56. Santos, L.O.; Moraes, L.A.C.; Petineli, R.; Moretti, L.G.; Moreira, A. Yield, Yield Components, Soil Fertility, and Nutritional Status of Soybean as Influenced by Limestone and Copper Interactions. J. Plant Nutr. 2020, 43, 2445-2454. [CrossRef]

57. Moreira, A.; Moraes, L.A.C. Soybean Response to Copper Applied to Two Soils with Different Levels of Organic Matter and Clay. J. Plant Nutr. 2019, 42, 2247-2258. [CrossRef]

58. Moreira, A.; Moraes, L.A.C.; Schroth, G. Copper Fertilization in Soybean-Wheat Intercropping under No-Till Management. Soil Tillage Res. 2019, 193, 133-141. [CrossRef]

59. Urano, E.O.M.; Kurihara, C.H.; Maeda, S.; Vitorino, A.C.T.; Gonçalves, M.C.; Marchetti, M.E. Soybean Nutritional Status Evaluation. Pesq. Agropec. Bras. 2006, 41, 1421-1428. [CrossRef]

60. Manchanda, J.S.; Dhaliwal, S.S.; Kaur, A. Effect of Copper and Phosphorus Application on Nutrition and Dry Matter Yield of Soybean (Glycine max L.). Agric. Res. J. 2017, 54, 347-351. [CrossRef] 